WORKING PAPER 2/2018

BILATERAL CAPITAL FLOWS: TRANSACTION PATTERNS AND GRAVITY

Rogelio V. Mercado, Jr.

The South East Asian Central Banks (SEACEN) Research and Training Centre (80416-M) Kuala Lumpur, Malaysia 
WORKING PAPER 2/2018

BILATERAL CAPITAL FLOWS: TRANSACTION PATTERNS AND GRAVITY

Rogelio V. Mercado, Jr. *

February 2018

*Rogelio V. Mercado, Jr. (rogelio.mercado@seacen.org) is Senior Economist at The South East Asian Central Banks Research and Training Centre (The SEACEN Centre). The author is highly indebted to Camille Deduque, Christopher Gohrband, Y. Laachir, and Robert Wederkinck for their discussions on their respective country's Regional Balance of Payments Statistics. The author is likewise grateful to Hans Genberg and Cian Allen for helpful comments and suggestions. 


\begin{abstract}
Holdings of cross-border bilateral assets are highly responsive to information frictions, market size, transaction costs, and trade ties. But empirical support using transactions data are constrained by the lack of comprehensive bilateral capital flows data covering large sample of economies for several years across investment and investor types. One expects that as information frictions weaken, transaction costs decline, and trade links strengthen, financial transactions between two economies will rise. This paper tests this hypothesis. Using bilateral Financial Accounts data from the Regional Balance of Payments Statistics of 10 advanced economies_yielding an unbalanced panel with 182 country pairs-for 2000-2016, the results provide strong evidence on the significance of information frictions, bilateral trade, transaction costs, and market size on bilateral capital flows. However, the findings show varying sensitivities of domestic and foreign investors to information asymmetries and trade ties. Moreover, investors appear to be more responsive to domestic transaction costs and foreign market size effects, than the converse. This study demonstrates an application of using bilateral capital flows data in revealing the patterns of international financial market segmentation still prevailing in cross-border financial transactions.
\end{abstract}

Keywords: $\quad$ Bilateral Capital Flows, Gravity, Asset Trade, Information Frictions

JEL Classification: F21, F36, G11

Disclaimer: This Working Paper should not be reported as representing the views of SEACEN or its member central banks/monetary authorities. The views expressed in this Working Paper are those of the author(s) and do not necessarily represent those of SEACEN or its member central banks/monetary authorities. 
Abstract iii

1. Introduction 1

2. Theoretical Motivation and Related Literature 4

3. Data on Bilateral Capital Flows and Stylized Facts 8

4. Empirical Specifications and Data Sources 12

5. Results and Analysis $\quad 16$

5.1 Bilateral Capital Flows on Gravity Factors 16

5.2 Bilateral Capital Flows on Market Size and Transaction Costs 19

6. Concluding Remarks 20

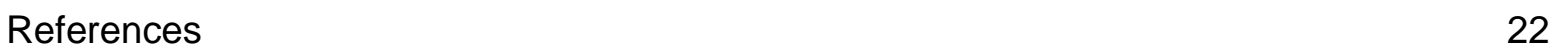

\section{Figures and Tables}

Figure 1: Schematic Diagram of Reporting 25

Table 1: Bilateral Capital Flows on Bilateral Holdings 26

Table 2: Summary of Bilateral Financial Flows $\quad 27$

Table 3: Descriptive Statistics Bilateral Capital Flows 28

Table 4: Bilateral Capital Flows, $2016 \quad 29$

Figure 2: United States Bilateral Capital Flows, 2016

Figure 3: Germany Bilateral Capital Flows, 2016

Figure 4: Japan Bilateral Capital Flows, 2016

Figure 5: United States Bilateral Total Assets and Liabilities Flows, 2016

Figure 6: Germany Bilateral Total Assets and Liabilities Flows, 2016

Figure 7: Japan Bilateral Total Assets and Liabilities Flows, 2016

Table 5: Bilateral Capital Flows on Gravity Factors 36

Table 6A: Bilateral Capital Flows on Gravity Factors 37

Table 6B: Bilateral Capital Flows on Gravity Factors 38

Table 6C: Bilateral Capital Flows on Gravity Factors 39

Table 6D: Bilateral Capital Flows on Gravity Factors $\quad 40$

Table 7: Bilateral Capital Flows on Market Size and Transaction Costs 41

Table 8A: Bilateral Capital Flows on Market Size and Transaction Costs 42

Table 8B: Bilateral Capital Flows on Market Size Transaction Costs 43

Table 8C: Bilateral Capital Flows on Market Size and Transaction Costs 44

Table 8D: Bilateral Capital Flows on Market Size and Transaction Costs 45 


\title{
BILATERAL CAPITAL FLOWS: TRANSACTION PATTERNS AND GRAVITY
}

\author{
By
}

Rogelio V. Mercado, Jr.

\section{Introduction}

Existing studies on the asset trade literature stress the significant role of information frictions, market size, trade links and transaction costs in segmenting cross-border financial transactions and holdings. The seminal work of Portes, Rey and Oh (2001), and Portes and Rey (2005) on bilateral portfolio transactions or flows; and Aviat and Coeurdacier (2007), Buch (2005), Lane and Milesi-Ferretti (2005a and 2005b) on bilateral portfolio and bank holdings provided both theoretical and empirical support in describing the differentiated cross-border investment patterns across asset types. The idea that international investment transactions and holdings gravitate towards specific markets that are usually large and sophisticated; and with less information frictions complements the international capital asset pricing model based on the portfolio allocation theory of Sharpe (1964) and Lintner (1965), which assumes frictionless markets. One expects that the more information frictions or the farther two economies are, the more likely they will hold each other's assets as they trade less and so their business cycles are uncorrelated. Given the enormous literature on the patterns of bilateral holdings, it is now well-established that distance, proxy for information asymmetries, explains asset trade as good as trade in goods. ${ }^{1}$

But there are still some gaps in the asset trade literature. Specifically, there are very few studies that consider asset transactions or capital flows in the context of gravity forces. Apart from Choi, Rhee and Oh (2014), Portes, Rey and Oh (2001), and Portes and Rey (2005) on portfolio flows, Brei and von Peter (2018), Herrmann and Mihaljek (2013) and Papaioannou (2009) on bank flows, and di Giovanni (2005) on mergers and acquisitions (M\&A), there is no study which considers all types of foreign- and domestic-driven investment flows as done by Daude and Fratzscher (2008) for asset holdings. Moreover, there is little discussion, apart from Portes and Rey (2005), on the link between asset holdings and transactions. Aside from information frictions, market size, trade links and transaction costs, it is expected that bilateral transactions should, likewise, depend on bilateral holdings. However, the relation between the two is not yet well-established such that the positive covariation between bilateral holdings and transactions may or may not hold in all cases.

\footnotetext{
1 See Aviat and Coeurdacier (2007), Blank and Buch (2007), Buch (2005), Coeurdacier and Martin (2009), Daude and Fratzscher (2008), Head and Reis (2008), Galstyan and Lane (2013), Galstyan, Lane, Mehigan, and Mercado (2016), Hellmanzik and Schmitz (2017), Lane and Milesi-Ferretti (2005a and 2005b), Lee (2008), Mehigan (2016), and Papaioannou (2009).
} 
This paper addresses these gaps in the literature. First, we assess the significance of information frictions, familiarity/similarity factors, financial centre effect, and trade ties on cross-border financial transactions using data on bilateral capital flows. Second, we examine the significance of reporter and partner country market size and transaction costs on bilateral transactions using data on bilateral capital flows. Based on existing theories and empirical evidence, we expect that as information frictions weaken, market size of partner country increase, transaction costs decline, and trade links strengthen, the financial transactions between two economies will increase in line with positive covariation between asset holdings and transactions.

The focus on bilateral transactions, instead of bilateral holdings, warrants justification. First, understanding bilateral financial flows or transactions informs us about the nature of information frictions economic agents face as well as the degree of cross-border market segmentation. Transaction patterns inform us of potential herding and arbitrage behavior, and cross-border spillovers. Second, bilateral financial transactions, which are essentially bilateral capital flows, informs us of the geographic distribution of aggregate capital flows and external positions, which have implications on the broader literature of capital flows determinants, volatilities, and episodes. Examining the significance of these gravitational forces on bilateral asset transactions has been constrained by the lack of comprehensive data which differentiates various forms of investments and investors. Hence, the novelty of this paper lies in its use of bilateral capital flows which enables us to assess the significance of gravitational forces on financial transactions across various types of investments (direct, portfolio, and other investments, which are primarily bank flows) and investors (domestic-driven asset flows and foreign-driven liabilities flows).

The bilateral capital flows data are sourced from the Regional Balance of Payments Statistics of 10 reporting central banks or statistics agencies; namely those from Austria (Österreichische Nationalbank), Canada (Statistics Canada), Denmark (Danmarks Nationalbank), Germany (Deutsche Bundesbank), Japan (Bank of Japan), Korea (Bank of Korea), Netherlands (De Nederlandsche Bank), New Zealand (Stats NZ), Spain (Banco de España) and United States (Bureau of Economic Analysis). The data set follows the Balance of Payments Manual 6. It covers annual values from 2000 to 2016, but yields an unbalanced panel comprising of 182 country pairs as reporting country values do not match the bilateral assets and liabilities of reporting partners. The stylized facts reveal the importance of financial centers as well as distance in shaping the geographic distribution of bilateral capital flows. Moreover, the crisis years of 2008-09 reflect bilateral banking flows retrenchment and sudden stop as other investment assets and liabilities have negative average values of around $0.06 \%$ and $0.01 \%$, of reporting country GDP, respectively, in this period. These stylized facts demonstrate that the observed patterns using aggregate capital flows also hold at the bilateral level. 
To examine the significance of gravitational forces on bilateral capital flows, we follow the two-step approach of Duade and Fratzscher (2008). First, we assess the significance of information frictions, proxied by bilateral distance, financial centre effect, and trade ties on bilateral capital flows across various types of investments and investors; namely: foreign direct investment assets (FDIA), foreign direct investment liabilities (FDIL), portfolio assets (PORTA), portfolio liabilities (PORTL), other investment assets (OIA), and other investment liabilities (OIL) using pooled OLS for 182 country pairs for 2000-2016. In this specification, we include common language, legal origins, and colonial ties to account for familiarity or similarity factors between country pairs. We also control for reporter-year and partner-year fixed effects, following Galstyan and Lane (2013), Galstyan, Lane, Mehigan, and Mercado (2016). Second, we focus on the relevance of transaction costs and market size on bilateral capital flows. For transaction costs, we include reporter and partner secure internet connection, control of corruption, and capital account openness. For market size, we use reporter and partner per capita income and financial centre effect. In our second specification, we control for time-invariant bilateral factors and year fixed effects.

The results offer new insights on the asset trade literature. The estimates indicate that bilateral capital flows are responsive to information frictions, financial centre effect, and trade ties, although their sensitivities to these gravitational forces depend on the type of investment and on whether financial transactions are domestic or foreign-driven. For instance, domestic investor-driven bilateral capital outflows are highly responsive to information frictions, proxied by bilateral distance, and on whether their partner country is a financial centre. However, across types of capital flows, it appears that other investment outflows do not respond to gravity factors unlike direct and portfolio outflows. In contrast, foreign investor-driven bilateral capital flows are highly sensitive to trade ties as bilateral gross capital inflows tend to be larger the stronger the trade ties between the two countries. Furthermore, the findings show that bilateral capital flows are more responsive to source country transaction costs than that of the destination country; while they are more sensitive to partner country market size, rather than their own.

In summary, using bilateral capital flows data, the findings in this paper show that crossborder transactions gravitate towards markets that are larger and those with less information asymmetries. These suggest that international financial markets remain fragmented by market size and information frictions, as first pointed out by Portes and Rey (2005), which is at odds with the implications of the portfolio allocation theory.

This paper proceeds as follows. Section 2 offers the theoretical motivation in line with the related literature on asset trade. We highlight the mechanics between distance, trade, and asset holdings; and bilateral transactions. Section 3 discusses the data on bilateral capital flows and offers stylized facts. Section 4 presents the empirical specifications and data sources. Section 5 discusses the benchmark results along with the battery of sensitivity tests. The first part focuses on the covariation between different kinds of bilateral flows and gravity 
factors; while the second part considers the covariation between bilateral capital flows and market size and transaction costs. Section 6 summarizes the paper.

\section{Theoretical Motivation and Related Literature}

The international capital asset pricing model, based on the traditional portfolio allocation theory of Sharpe (1964) and Lintner (1965), implies that domestic investors should hold equal amount of world risky assets. This allows domestic investors to diversify their portfolio holdings based on returns-risk trade-off. With the removal of capital controls and advances in information and communications technology, the costs of asset trading should have gone down, thereby increasing cross-border asset holdings and transactions and intensifying global financial integration. However, Portes and Rey (2005) show that the gravity model explains international financial transactions as well as trade in goods. They argue for the presence of cross-border financial market segmentation wherein bilateral capital flows are geared towards partner countries where there are less information frictions. This extends the portfolio allocation theory as one would expect that the more information frictions or the farther two economies are, the more likely they would hold each other's assets as they trade less and so their business cycles are uncorrelated (Baxter and Kouparitsas, 2005; and Portes, Rey and Oh, 2001).

To address this contradiction, Portes and Rey (2005) developed a general equilibrium model of bilateral cross-border asset transactions where a gravity equation emerges on the account of the following. First, assets are imperfect substitutes as they insure against varying risks. Second, asset trade entails trade costs in the form of information and transaction costs. Lastly, the supply of assets is endogenous as risk-averse agents develop optimal number of Arrow-Debreu securities that corresponds to different assets traded in the stock market i.e. higher asset demand leads to higher asset price and therefore more listings. The corresponding model follows a gravity equation.

$$
\log T_{i j}=k_{1} \log \left(M_{i} M_{j}\right)+k_{2} \log \left(\tau_{i j}\right)+k_{3} \quad \text { Equation (1) }
$$

where $T_{i j}$ is asset transactions from country $i$ to country $j, M_{i}$ and $M_{j}$ are measures of market size of countries $i$ and $j$, respectively, $\tau_{i j}$ refers to the trading costs between countries $i$ and $j$, and $k_{1}>0, k_{2}<0$, and $k_{3}$ are constants. This theoretical model implies that country size is an important determinant of financial flows as a larger population allows more investors to retain fewer ownership of projects and issue more shares in the stock market-thereby increasing the size and sophistication of domestic equity market. Consequently, economies with deeper and more sophisticated stock market emerge as a financial centre which attracts 
cross-border listings and even greater volume of transactions (Martin and Rey, 2004). ${ }^{2}$ The model also highlights the importance of asset trading costs which involves both information and transaction costs. Information costs pertain to information asymmetries between two countries, which are related to distance, common language, legal origins, colonial ties, and the like.

In the standard trade theory, distance is a proxy for transport cost. The farther two countries are, the greater the transportation costs, and hence the lower the bilateral trade. But in the asset trade literature, financial instruments are supposed to be "weightless". To address this ambiguity, Portes, Rey and Oh (2001) and Portes and Rey (2005) suggest that distance is a proxy for information frictions or asymmetries. They argue that countries close to one another transact more through direct interaction such as business ties, frequent travels, media coverage, and language familiarity. Empirical support for this interpretation has been limited in the context of cross-border transactions or capital flows. Choi et al. (2014), Portes, Rey and Oh (2001); and Portes and Rey (2005) find negative covariation between portfolio equity flows and distance. Brei and von Peter (2018), Herrmann and Mihaljek (2013) and Papaioannou (2009) show the inverse relation using bilateral bank flows from the Bank for International Settlements (BIS) Locational Statistics. di Giovanni (2005) find similar results for foreign direct investment using Thomson Financial data on mergers and acquisitions (M\&A). In contrast, most studies on asset trade offer more evidence on the negative covariation between asset holdings and distance. Head and Reis (2008) focus on bilateral foreign direct investment holdings using OECD FDI data. Galstyan and Lane (2013), Galstyan, Lane, Mehigan, and Mercado (2016), Hellmanzik and Schmitz (2017), Lane and Milesi-Ferretti (2005a and 2005b), and Lee (2008) use bilateral portfolio asset holdings from the International Monetary Fund's Coordinated Portfolio Investment Survey (CPIS). Aviat and Coeurdacier (2007), Blank and Buch (2007), Buch (2005), and Mehigan (2016) employ bilateral bank claims and liabilities from BIS Banking Statistics, while Daude and Fratzscher (2008) construct a comprehensive data set which includes all types of asset holdings such as direct, portfolio equity, portfolio debt, and bank loans. ${ }^{3}$

\footnotetext{
2 In contrast, Okawa and van Wincoop (2012) derived a theoretical gravity equation where bilateral asset holdings depend on the product of economic size variables and relative frictions. In their model, bilateral frictions include distance, common language, legal origins, colonial ties and the like. Source or destination information frictions such as regulatory quality and financial sophistication are included in their model through dummy variables, which also capture asset returns, volatilities, and covariances.

${ }^{3}$ These studies demonstrate the overwhelming significance of information frictions, which includes bilateral distance, on cross-border asset holdings and transactions. However, information asymmetries have varying interpretation and significance across types of assets. For foreign direct investment, distance directly impacts asset holdings because monitoring costs increase with distance. However, there is also an indirect effect via bilateral trade (Aviat and Coeurdacier, 2007; and Lane and MilesiFerretti, 2005a). For cross-border bank loans, distance increases bank monitoring costs particularly for foreign currency claims and liabilities (Kleinert, Brueggemann, and Prieto, 2012). Daude and Fratzscher (2008) find that foreign direct investment and bank loans are more sensitive to information frictions contrary to the view that portfolio holdings must be more responsive to information asymmetries due to the lack of ownership or control. In contrast, they show portfolio holdings are more sensitive to institutional quality.
} 
Apart from distance, information frictions also include common bilateral factors such as language, legal origins, and colonial ties. These time-invariant factors suggest the degree of similarity between countries. Common language, legal origins, and colonial ties-which increase familiarity between country pairs-also reduce information frictions, thereby increasing bilateral holdings and transactions. Specifically, common language fosters greater information flows as it reduces translation costs and increases access to available information. Common legal origins facilitate easier settlements and improves contract enforcement; while colonial ties increase similarities between two countries due to similar institutional set-up (Head and Ries, 2008). Empirical evidence on the relevance of these bilateral factors are robust. For bilateral transactions, Brei and von Peter (2018) and di Giovanni (2005) find country pairs with common language and colonial ties have larger bilateral bank and FDI flows, respectively. For bilateral holdings, Head and Ries (2008) show country pairs with common language and colonial links have significantly higher bilateral foreign direct investments. Galstyan and Lane (2013), Galstyan, Lane, Mehigan, and Mercado (2016), Hellmanzik and Schmitz (2017), Lane and Milesi-Ferretti (2005a), and Lee (2008) show the same positive covariation between colonial ties, legal origins and common language; and portfolio holdings. Aviat and Coeurdacier (2007), Blank and Buch (2007), Buch (2005), Coeurdacier and Martin (2009), and Mehigan (2016) find countries with common language, legal origins, and colonial ties have higher bilateral bank claims and liabilities; while Daude and Fratzscher (2008) showed similar results across different types of assets.

Asset trade not only involves information costs but transaction costs as well. These transaction costs pertain to both direct and indirect barriers to asset trade. Any measures from both or either the source and/or destination country that influence the value and volume of cross-border asset holdings and transactions are direct barriers to asset trade. These include investment limits and/or taxes, exchange rate fluctuations, common currency, economic associations, and advances in information and communications technology. For instance, capital controls, banking commissions, and variable fees that limit and/or tax cross-border investments increase transaction costs and thereby discourages cross-border holdings and transactions (Buch, 2005; Herrmann and Mihaljek, 2013; and Martin and Rey, 2004). Fixed exchange rate and common currency reduce currency risks and transaction costs and lead to asset trade diversion. These also foster bilateral investments (Coeurdacier and Martin, 2009; Galstyan and Lane, 2013; Galstyan, Lane, Mehigan, and Mercado, 2016). Economic ties through trade agreements, customs and economic unions, and tax treaties lower or eliminate direct barriers to asset trade, which reduces direct transaction costs and increases crossborder holdings and capital flows (Blank and Buch, 2007; Daude and Fratzscher, 2008; di Giovanni, 2005; Galstyan and Lane, 2013; Lane and Milesi-Ferretti, 2005a, Martin and Rey, 2004; and Mehigan, 2016). Likewise, advances in information and communications technology which allow for greater access to information flows and lower communication costs, such as internet and telephone calls, reduce transactions costs and simulate crossborder investments (Choi, Rhee and Oh, 2014; Daude and Fratzscher, 2008; Hellmanzik and Schmitz, 2017; Portes, Rey and Oh, 2001; and Portes and Rey, 2005). 
In contrast to direct barriers, qualities of both or either the source and/or destination country that encourage or discourage asset holdings and transactions through greater or less information frictions are indirect barriers to asset trade. ${ }^{4}$ These include accounting standards, regulatory quality, property rights, control of corruption, and institutional quality (Daude and Fratzscher, 2008; Papaioannou, 2009; and Wei and Wu, 2002). In fact, Daude and Fratzscher (2008) discover that institutional quality has varying impacts on different types of assetssuch that portfolio investment is more responsive to regulatory quality compared to foreign direct investment and bank holdings. Furthermore, Daude and Fratzscher (2008) and Wei and $\mathrm{Wu}$ (2002) show that corruption reduces foreign direct investment holdings, although Wei and Wu (2002) note that corruption tends to increase bank lending, suggesting that direct investors are more cautious than banks due to possible bank bailouts from international financial institutions in the event of debt default. Such implicit guarantees do not exist for both greenfield investments and mergers and acquisitions.

Aside from trading costs, asset holdings positively covary with bilateral trade. Several theories are proposed. First, Lane and Milesi-Ferretti (2005a) extended the Obstfeld and Rogoff (2001) model to $\mathrm{N}$ country case. The intuition is as follows. Country A does not trade with country $B$. But country A imports from country $C$. Suppose there is a productivity shock in country $C$ which lower its prices, country $A$ will suffer losses as it will import more from country $\mathrm{C}$. To hedge against its losses, country A should hold portfolio assets of country $\mathrm{C}$. Hence, higher trade leads to higher portfolio holdings. In contrast, Coeurdacier (2009) highlights the role of lower trade cost, which increases bilateral trade. As trade intensifies, domestic firms face greater competition. To hedge against losses, a country must hold equity of foreign firms which directly compete with domestic firms. This also explains the positive relation between trade and asset holdings. The second explanation is more in line with Portes and Rey (2005). The intuition goes as follows: shorter distance reduces information frictions and lowers transaction costs. These lead to higher bilateral trade. As information frictions decline, asset holdings also increase, more so when equity market expands (Martin and Rey 2004). Third, another theoretical underpinning is provided by Rose and Spiegel (2002) and Rose (2005) in the context of debt default. These authors argue that countries fear debt default because it cuts them off from international capital markets and leads to trade reduction, hence output drop. Consequently, creditors favour debtor countries who they have greater trade ties. Various studies provide strong empirical support on the positive covariation between bilateral trade and bilateral holdings. ${ }^{5}$

\footnotetext{
4 The notion that information asymmetries can affect indirect barriers to asset trade is in line with Ahearne, Griever, and Warnock (2004) and Okawa and van Wincoop (2012).

5 They include di Giovanni (2005) for foreign direct investment; Galstyan and Lane (2013), Galstyan, Lane, Mehigan, and Mercado (2016), Hellmanzik and Schmitz (2017), Lane and Milesi-Ferretti (2005a and 2005b) and Lee (2008) for portfolio holdings; Aviat and Coeurdacier (2007), Blank and Buch (2007), Coeurdacier and Martin (2009), and Mehigan (2016) for bank holdings; Duade and Fratzscher (2008) for all types of holdings; Portes and Rey (2005) for equity flows; and Herrmann and Mihaljek (2013) for bank flows.
} 
Asset transactions not only depend on market size, information asymmetries, transaction costs and bilateral trade, but also on the amount of existing asset holdings. For instance, Portes and Rey (2005) and Herrmann and Mihaljek (2013) implicitly assume that asset holdings and transactions positively covary such that higher holdings lead to higher transactions. In fact, Portes and Rey (2005) show that the elasticity of US residents' transactions in foreign corporate equities with respect to US holdings in those equities is close to one. However, the theoretical framework explaining the covariation between transactions (flows) and holdings (stock) remains non-existent. Nonetheless, stock-flow adjustment equation sheds some light on the mechanics for such theoretical framework. Recall:

$$
X_{t}-X_{t-1}=F L O W_{t}+V A L_{t}+O T H_{t} \quad \text { Equation (2) }
$$

using some transpositions,

$$
F L O W_{t}=X_{t}-X_{t-1}-V A L_{t}-O T H_{t} \quad \text { Equation (3) }
$$

where $X$ are stock positions or holdings at time $t$ and $t-1 ; F L O W_{t}$ is the capital flows or transactions at time $\mathrm{t}, V A L_{t}$ refers to the valuation effects which include changes in market prices, exchange rates, and write-downs, and $O T H_{t}$ pertains to the residual term which reflects gaps and revisions of the stock holdings data. Based on Equations (2) and (3), in the absence of valuation effects and data revisions, we can consider cases when the net change in stock holdings are positive and hence there is positive covariation between asset holdings and transactions. In fact, we confirm the significant positive covariation of bilateral capital flows and holdings. ${ }^{6}$ With this in mind, the mechanics between information frictions, transaction costs, and trade ties; and bilateral holdings and transactions can be summarized as follows. Greater information frictions reduce bilateral holdings which positively covaries with bilateral capital flows. Higher transaction costs increase trading costs which lowers bilateral holdings and hence bilateral capital flows. Larger bilateral trade reduces information frictions and increases bilateral asset holdings and transactions. These are the hypotheses which this paper tests using bilateral capital flows data.

\section{Data on Bilateral Capital Flows and Stylized Facts}

To assess the significance of information frictions, transactions costs, and market size on cross-border asset trade, this paper uses bilateral Financial Accounts data from the

\footnotetext{
${ }^{6}$ We conduct an exercise by regressing bilateral capital flows on bilateral asset holdings. Bilateral direct and portfolio holdings are sourced from the Coordinated Direct Investment Survey and Coordinated Portfolio Investment Survey of the International Monetary Fund, respectively. Data on bank holdings come from the BIS; while bilateral capital flows are taken from national sources including central banks and statistics agencies. The results, presented in Table 1, show that bilateral capital flows positively covary with their respective holdings across different types of investments.
} 
Regional Balance of Payments Statistics. Previous analysis on bilateral cross-border investment flows are confined to one type of asset-either direct, portfolio, or bank loansdue to the lack of comprehensive data covering various types of capital flows. Brei and von Peter (2018) and Herrmann and Mihaljek (2013) use BIS Locational Banking Statistics to understand information frictions in the context of banking flows. di Giovanni (2005) exploit Thomson Financials data on bilateral mergers and acquisitions. Choi et al. (2014) and Portes, Rey and Oh (2011) use U.S. Treasury International Capital data, while Portes and Rey (2015) use Cross Border Capital dataset to assess the role of gravity factors on bilateral equity flows.

An advantage of using bilateral data on capital flows is that it allows comparison across different forms of investments, thereby offering a wider understanding of cross-border investment patterns. More importantly, as the data are aligned with the Balance of Payments accounting standards, data composition are richer. For instance, di Giovanni (2005) does not consider transactions involving greenfield investments; while Brei and von Peter (2018) and Herrmann and Mihaljek (2013) exclude non-bank reported transactions, pensions, insurance, and special drawing rights in their analysis of bilateral banking flows, although these are all included in other investment category of the bilateral Financial Account. However, there are downsides as well. First, there are very few countries which report bilateral Balance of Payments. For those that do, most partner economies are grouped or aggregated at the regional level, perhaps due to confidentiality reasons. Second, bilateral capital flows mostly capture cross-border transactions with financial centres as foreign counterparty are usually financial intermediaries and custodians located in financial centres such as London (Warnock and Cleaver, 2003). Therefore, we cannot conduct analysis in the context of portfolio choice or investment decisions, instead our analysis involves understanding international financial market segmentation.

Figure 1 presents a schematic diagram illustrating the complexities of using data on bilateral capital flows. Figure 1a on bilateral asset flows show that some transactions are recorded based on the country of the ultimate owner, issuer and/or beneficiary. But most bilateral transactions are reported based on the location of transacting counterparty such as those using financial intermediaries and/or custodians. In the latter case, the country location of the ultimate owner, issuer, or beneficiary may or may not be known. To illustrate, if a company in the reporting country acquires a company in country $C$ through an intermediary in country $\mathrm{B}$, bilateral transactions will be recorded between the reporting country and country $B$, even if the actual money has flown from the reporting country to country $C$. Figure $1 \mathrm{~b}$ on bilateral liabilities also demonstrates the same idea. In practice, most countries report bilateral transactions based on the country location of the counterparty involved in that transaction. However, initiatives are made to report some categories of the bilateral Financial Account based on the location of the ultimate owner, issuer or beneficiary, like in the case of the Netherlands. Table 2 summarizes the bilateral capital flows data and indicates whether each functional category of the Financial Account refers to the country location of the transacting counterparty (TC) or the country location of the ultimate owner, issuer or beneficiary (UOIB). 
The table reveals that that most values of the bilateral financial flows pertain to the country location of the transacting counterparty.

The bilateral capital flows data are taken from Regional Balance of Payments Statistics of 10 reporting central banks or statistics agencies, including Austria (Österreichische Nationalbank), Canada (Statistics Canada), Denmark (Danmarks Nationalbank), Germany (Deutsche Bundesbank), Japan (Bank of Japan), Korea (Bank of Korea), Netherlands (De Nederlandsche Bank), New Zealand (Stats NZ), Spain (Banco de España) and United States (Bureau of Economic Analysis). ${ }^{7}$ Values are mostly presented in local currency units. To standardize across countries, data are converted to US dollar (in millions) using the average foreign exchange rate taken from the International Financial Statistics of the IMF. ${ }^{8}$ The data set covers annual values from 2000 to 2016 . For some countries, quarterly or monthly data in US millions are added annually. Confidential and unavailable data are treated as missing values; whereas zeros are included as they are. Reported values follow the Balance of Payments Manual 6 (BPM6), but in cases where values are based on Balance of Payments Manual 5, e.g. Japan for 2000-2013, bilateral assets are multiplied by -1 in lieu of BPM6 convention of having a positive sign to indicate an increase in assets or liabilities. There are 182 bilateral pairs, with Denmark, Germany, Japan, and New Zealand having more than 30 partner countries.

The various types of bilateral capital flows include foreign direct investment assets (FDIA), foreign direct investment liabilities (FDIL), portfolio assets (PORTA), portfolio liabilities (PORTL), other investment assets (OIA), and other investment liabilities (OIL). ${ }^{9}$ If bilateral total assets and liabilities are given, they are used in the data set. If not, total assets are computed as the sum of direct, portfolio, financial derivative, other investment and official reserve assets whenever data are available. ${ }^{10}$ Total liabilities are computed as the sum of direct, portfolio, financial derivative, and other investment liabilities whenever data are

\footnotetext{
7 There are other countries which could have been included in the data set. For instance, France reports bilateral capital flows for direct and portfolio investments, but not for other investments which could have been supplemented by using bilateral bank flows from the BIS locational banking statistics. However, we opt to restrict our sample to those countries which report the complete functional category of the Balance of Payments. Nonetheless, the sample size is representative of the global sample given the inclusion of the United States, Japan, and Germany. On the average, the sample accounts for about $35-40 \%$ of total holdings of direct and portfolio investments and bank claims and liabilities.

${ }^{8}$ Given that we used nominal GDP of the reporting country in US millions, we remove any exchange rate effects in our bilateral capital flows.

9 For Austria, foreign direct investment data mostly include direct investments of Special Purpose Entities (SPEs) and real estate sector. However, for some economies, reported foreign direct investment assets and liabilities exclude these items. In addition, portfolio liabilities data for Austria and the Netherlands are estimated by multiplying total portfolio liabilities with bilateral weights, computed as the share of derived portfolio liabilities of a partner country to total world liabilities of Austria and the Netherlands, respectively, sourced from the IMF's CPIS.

${ }^{10}$ Foreign direct investment includes both greenfield and mergers and acquisitions. Portfolio includes both equity and bonds, while other investment flows mostly capture bank lending flows across various sectors.
} 
available. ${ }^{11}$ Following the naming convention in the capital flows literature, asset transactions are gross capital outflows, while liabilities are gross capital inflows. Hence, bilateral assets and liabilities are bilateral gross capital outflows and inflows, respectively. Moreover, bilateral gross capital outflows are domestic-driven transactions; while bilateral gross capital inflows are foreign-driven.

Table 3 provides descriptive statistics on bilateral capital flows in percent of the reporter country nominal GDP. Several observations are noted. For the full sample period of 2000-16, the average bilateral portfolio inflows and outflows is about $0.1 \%$ of the reporting country's nominal GDP. In contrast, the relative size of average bilateral flows is smallest for other investment flows at around $0.06 \%$. Across sub-periods, the average bilateral flows are higher in the pre-global financial crisis period of 2000-07. In fact, the average bilateral portfolio flow is around $0.2 \%$ of reporting country's nominal GDP, while the average bilateral other investment flow is around $0.1 \%$. The crisis years of 2008-09 reflect bilateral banking flow retrenchment and sudden stop as other investment assets and liabilities have negative average values of around $0.06 \%$ and $0.01 \%$, respectively. This is in line with Milesi-Ferretti and Tille (2011) who argue that capital flow retrenchment (reversal of domestic investor gross banking outflows) and sudden stop (reversal of foreign investor gross banking inflows) are driven by risk uncertainty during the height of the global financial crisis. Hence, such reversals of capital flows during extreme episodes which we see in the aggregate financial account statistics also hold at the bilateral level, although of course, the average magnitude of reversals for bilateral flows are smaller. Lastly, the average bilateral flows during the postcrisis years of 2010-16 are smaller than the averages during the pre-crisis years of 2000-07, which implies that the pre-crisis years is an exceptional period in terms of cross-border financial investments.

Table 4 shows the values of bilateral capital flows for selected reporting and partner countries for 2016. The striking pattern we see is that portfolio and other investment inflows from the United Kingdom is particularly huge for Germany and Japan. This clearly illustrates the role of United Kingdom as a global financial centre (Warnock and Cleaver, 2003). Given that the data reflects the country location of the transacting counterparty, we could infer that a large share of this amount can be attributed to the transactions of financial intermediaries or custodians based in London. In addition, the table reveals that the reported values of United States do not match the reported values of Germany and Japan for the United States. This mismatch is primary due to differences in reporting standards between countries. In Japan's case, the differences are substantial, while for Germany, the discrepancies are smaller. In this regard, we cannot derive mirror data based on reported values to increase the sample size as done by the IMF in their Coordinated Portfolio Investment Survey.

\footnotetext{
${ }^{11}$ Data on financial derivative assets and liabilities and reserve assets are available for a limited number of countries. Moreover, financial derivative assets are reported mostly in net terms. For these reasons, analysis involving different types of capital flows are restricted to the main functional categories. Nonetheless, data on derivatives and reserves are included in computing total financial assets and liabilities.
} 
Figures 2-4 present the geographic breakdown of different types of bilateral flows for the United States, Germany, and Japan in 2016, respectively. For the United States (Figure 2), bilateral flows from the rest of the world is large. For Germany (Figure 3), portfolio and other investment inflows mostly come from United Kingdom and Euro Area countries, hinting at the importance of distance on Germany's bilateral inflows. For Japan (Figure 4), bilateral outflows usually go to the United States, whereas bilateral inflows mostly come from Euro Area and United Kingdom. To the extent that most of Japan's bilateral flows involve geographically distant economies, it can be inferred that information frictions, transaction costs, and even trade ties play a limited role in Japan's bilateral financial transactions. ${ }^{12}$ Figures 5-7 split the bilateral flows to and from the United States, Germany, and Japan into advanced and emerging economies, where advanced economies include those as defined by the World Economic Outlook Database of the International Monetary Fund while emerging economies include those that are not advanced economies. The figures show bilateral flows from advanced economies are larger and more volatile compared to emerging economies. This observation is intuitive given that advanced economies are more integrated with the global financial system and have more assets and liabilities to transact with.

In summary, stylized facts using bilateral capital flows demonstrate that the observed patterns using aggregate capital flows also hold at the bilateral level. However, bilateral capital flows data are complicated by transactions involving financial centre, small sample size, and country differences in reporting systems. Nonetheless, the use of bilateral capital flows remains informative in understanding patterns of international investment flows.

\section{Empirical Specifications and Data Sources}

To address the first question in this paper on the significance of information frictions, financial centre effect, and trade ties on bilateral capital flows, we closely follow the gravity model specification used in the asset holdings literature. ${ }^{13}$ Specifically, we estimate the following equation:

$$
C F_{i j, t}^{k}=\alpha_{i, t}^{k}+\alpha_{j, t}^{k}+g_{i j} \theta^{k}+\beta^{k} F C_{j}+h_{i j, t} \phi^{k}+\varepsilon_{i j, t} \quad \text { Equation (4) }
$$

where $C F_{i j, t}^{k}$ are bilateral capital flows of type k, from reporter country $\mathrm{i}$ to partner country $\mathrm{j}$ at year t. $\alpha_{i, t}^{k}$ and $\alpha_{j, t}^{k}$ are reporter-year and partner-year dummy variables, respectively, which accounts for time-varying reporter and partner factors. $g_{i j} \theta^{k}$ is a row vector of bilateral timeinvariant gravity variables including distance, common language, common legal origins, and

\footnotetext{
12 Japan, likewise, has substantial share of portfolio assets holdings outside the East Asia region, although its bilateral trade within the Asian region is larger compared to other regions.

${ }^{13}$ We closely follow Galstyan and Lane (2013), Galstyan, Lane, Mehigan, and Mercado (2016), Hellmanzik and Schmitz (2017), and Lane and Milesi-Ferretti (2005a and 2005b).
} 
colonial ties. $\quad \beta^{k} F C_{j}$ is a dummy variable which takes the value of 1 if the partner country is a financial centre; and 0 otherwise. $h_{i j, t} \phi^{k}$ is a row vector of bilateral time-varying variables such as lagged bilateral trade and membership in a common currency or fixed exchange rate regime. $\varepsilon_{i j, t}$ pertains to robust standard errors.

We run a pooled OLS estimation with "double fixed effect" to account for time-varying source and host factors, like Galstyan and Lane (2013), Galstyan, Lane, Mehigan, and Mercado (2016), Hellmanzik and Schmitz (2017). This specification is also consistent with the theoretical model of Okawa and van Wincoop (2012) and estimation approach suggested by Baldwin and Taglioni (2007). Unlike Galstyan and Lane (2013), we do not use generalized least squares to account for non-spherical disturbance term, given that our data set is an unbalanced panel i.e. residuals of country j to country i mostly do not exist. ${ }^{14}$ Hence, we opt to use OLS estimation with robust standard errors. We do not include various types of stock positions in our specification as they should be absorbed by the country-year dummy variables. In addition, bilateral stock holdings are not included as they will be highly endogenous with bilateral transactions as discussed in Section $2 .{ }^{15}$ Furthermore, the exclusion of bilateral holdings is consistent with the mechanics between gravity factors, bilateral holdings with bilateral transactions.

The bilateral capital flows data are expressed in percent of reporting country nominal GDP, following Aviat and Coeurdacier (2007). Scaling bilateral flows in terms of nominal GDP allows us to interpret the coefficients in terms of relative size instead of elasticities as widely used in the literature. An advantage of using relative magnitude is that it addresses the issue of having zeros and negative values in the data set due to reversals of capital flows. The reporter-year and partner-year dummy variables capture time-varying push and pull factors of source and destination countries. They also absorb portfolio dynamics, exchange rate fluctuations, asset price movements, and multilateral resistance (Galstyan and Lane, 2013; and Okawa and van Wincoop, 2012). The time-invariant gravity factors are measures of information frictions. We expect that distance decreases bilateral flows, while common language, common legal origins, and colonial ties increase bilateral transactions as they proxy for familiarity or similarity between country pairs. To account for financial centres as pointed out by Warnock and Cleaver (2003), we include a dummy variable which takes the value of 1

\footnotetext{
${ }^{14}$ Except when the reporting countries have available data on their bilateral capital flows with other reporting countries e.g. United States and Germany; and Germany and United States.

${ }_{15}$ We estimated Equation (4) including bilateral stock positions sourced from the CDIS, CPIS, and BIS Locational Banking Statistics. The results show that bilateral holdings are significantly positive for portfolio and other investment flows. Unlike the baseline results where distance and trade appear significant for most types of outflows (assets) and inflows (liabilities), respectively, distance is significant with the correct sign only for portfolio (assets) outflows while bilateral trade is relevant with the right sign for only portfolio (liabilities) inflows. We take this as evidence of endogeneity between the bilateral factors and bilateral holdings which biases the results. Hence, we do not include bilateral holdings in our specifications.
} 
if the partner country is a financial centre and 0 otherwise. ${ }^{16}$ The estimated coefficient will indicate how large bilateral flows are going to financial centres. Lagged bilateral trade and membership in a fixed exchange rate regime are included to capture time-varying bilateral factors. We expect that the larger the lagged bilateral trade, proxied by imports of country $i$ to country $\mathrm{j}$ in percent of country i's nominal GDP, the larger bilateral transactions as importing countries hedge against possible losses and debt default of their partner country. Fixed exchange rate, which includes common currency, lowers bilateral trade costs and increases bilateral holdings and transactions.

Data on bilateral capital flows are sourced from central banks or statistics agencies of reporting economies. Values are scaled by the nominal GDP of the reporting country, taken from the World Economic Outlook Database. Distance is in natural log value of the populationweighted distance between country pairs. Colony is also a dummy variable with a value of 1 if country pair has a common colonizer post-1945; and 0 otherwise. Legal is a dummy variable with a value of 1 if a country pair has a common legal origin; and 0 otherwise. Language is dummy variable with a value of 1 if a country pair has a common official or primary language; and 0 otherwise. These gravity variables are sourced from the CEPII Database. Financial centre is also a dummy variable with a value of 1 if the partner country is a global financial centre or an offshore financial centre; and 0 otherwise. The data set is constructed using information from the Global Financial Centres Index (2017) and IMF Staff Assessments on Offshore Financial Centres. ${ }^{17}$ Data on bilateral trade is the lagged natural log value of bilateral imports between reporter and partner countries sourced from IMF's Direction of Trade Statistics. Values are lagged to address potential endogeneity issues. Fixed exchange rate is also a dummy variable with a value of 1 if a country pair has a common currency or a fixed exchange rate regime; and 0 otherwise. The data is compiled using information from individual central banks and IMF's AREAR for 2012 to 2016.

Equation (4) considers the significance of bilateral factors, including information frictions and trade ties, affecting financial transactions. However, it does not capture the relevance of market size and transactions costs on bilateral capital flows as they are subsumed by the report-year and partner-year fixed effects. Following Portes and Rey (2005) and Duade and Fratzscher (2008), we run a separate pooled OLS estimation to assess the impact of reporter and partner factors on bilateral investment flows. Specifically, we estimate:

\footnotetext{
${ }^{16}$ Galstyan and Lane (2013), Galstyan, Lane, Mehigan, and Mercado (2016), and Lane and MilesiFerretti (2005a and 2005b) exclude offshore financial centres in their sample. In this paper, we include all financial centres-either they are global or offshore financial centres-as the main interest of this paper is to understand the role of information asymmetries, bilateral trade, and transaction costs in describing segmentation of international financial markets.

17 Financial centres in this sample include both offshore (Bermuda, British Virgin Islands, Cayman Islands, Cook Islands, Cyprus, Ireland, Netherlands Antilles, and United Arab Emirates) and global financial centres (Canada, China, France, Germany, Hong Kong, Japan, Singapore, Switzerland, United Kingdom, and United States).
} 


$$
C F_{i j, t}^{k}=m_{i, t-1} \theta^{k}+n_{j, t-1} \phi^{k}+z_{i j}+t_{t}+\varepsilon_{i j, t}
$$

where $C F_{i j, t}^{k}$ are bilateral capital flows of type k, from reporter country $\mathrm{i}$ to partner country $\mathrm{j}$ at year t. $m_{i, t} \theta^{k}$ and $n_{j, t} \phi^{k}$ are row vectors of time-varying reporter and partner domestic factors including market size and transactions costs, respectively. $z_{i j}$ are time-invariant bilateral dummy variable, while $t_{t}$ is year dummy variable. As usual, $\varepsilon_{i j, t}$ pertains to robust standard errors. As in Equation (4), we do not use generalized least squares (GLS) to account for nonspherical disturbance term as our data set is an unbalanced panel i.e. residuals of country $j$ to country i mostly do not exist, except when the reporting countries have available data on their bilateral capital flows with other reporting countries e.g. United States and Germany; and Germany and United States. Hence, we still use OLS estimation with robust standard errors. As we are focusing on domestic factors, we use lagged values of the reporter and partner countries to address potential endogeneity. Like Equation (4), we do not include various types of bilateral stock positions as they will be highly endogenous with transactions as mentioned.

Consistent with Martin and Rey (2004) and Portes and Rey (2005), we expect market size, proxied by real per capita income, of both source and host countries to have positive impact on bilateral transactions. Financial centres, likewise, account for market size and sophistication of the reporter and partner countries. The internet increases information flows and reduces direct transaction costs, which should foster greater bilateral capital flows (Choi, Rhee and Oh, 2014; and Hellmanzik and Schmitz, 2017). Unlike Portes and Rey (2005) and Daude and Fratzscher (2008) who use telephone calls, we use secure internet connection as proxy for direct transactions costs as most financial transactions are nowadays conducted using the internet. Our measure of internet connection accounts for the costs involved using encrypted data. Control of corruption, which reflects institutional quality, reduces transaction costs and lessens information frictions (Daude and Fratzscher, 2008; Papaioannou, 2009; and Wei and Wu, 2002). Capital account openness lowers transaction costs and thereby encourages cross-border transactions (Buch, 2005; Herrmann and Mihaljek, 2013; and Martin and Rey, 2004). Unlike Equation (4), Equation (5) uses time-invariant bilateral and year dummies to capture variation in reporter and partner factors.

Data on real per capita income are lagged natural log values of GDP per capita in constant 2010 US dollar. Internet pertains to lagged natural log value of secure internet servers per 1 million people. Missing data for some countries are filled in using values for years with available data. Values for per capita income and secure internet connection are taken from World Bank's World Development Indicators. Data on control of corruption are lagged values of reporter and partner country percentile rank based on World Bank's World Governance Indicators. Higher percentile rank means less corruption. Values in 2000 and 2002 are used to fill in data for 1999 and 2001, respectively. Capital account openness are 
lagged normalized capital account openness index of the reporter and partner countries sourced from Chinn and Ito (2006). Higher values imply greater capital account openness.

\section{Results and Analysis}

\subsection{Bilateral Capital Flows on Gravity Factors}

Baseline Results. Table 5 presents the baseline results examining the role of information frictions, financial centre, and trade ties on bilateral capital flows. Columns (1) to (4) pertain to bilateral asset transactions (gross capital outflows), while Columns (5) to (8) refer to bilateral liabilities (gross capital inflows). Columns (1) and (5) are total bilateral gross capital outflows and inflows, respectively. Columns (2) and (6) are bilateral gross FDI outflows and inflows, respectively. Columns (3) and (7) are bilateral gross portfolio outflows and inflows, respectively; while Columns (4) and (8) are bilateral gross other investment outflows and inflows, respectively. Following Choi, Rhee and Oh, 2014, gross outflows are driven by domestic investors, while gross inflows are foreign-driven. Across types of capital flows, the baseline gravity specification explains around $40 \%$ to $60 \%$ of the sample variation. This suggests that the regression model explains the variation of the different types of bilateral capital flows reasonably well.

The benchmark results show that domestic investor-driven bilateral gross capital outflows are highly responsive to information frictions as proxied by bilateral distance. This is consistent with earlier findings using bilateral transactions data including those from Brei and von Peter (2018), Choi, Rhee and Oh, 2014, di Giovanni (2005), Herrmann and Mihaljek (2013), Portes and Rey (2005), and Portes, Rey and Oh (2001). Specifically, doubling the distance between two country pairs reduces total bilateral transactions, on the average, by about $0.05 \%$ of the reporting country's GDP. The same significant negative covariation between distance and bilateral asset flows hold for foreign direct and portfolio investments. ${ }^{18}$ In contrast, distance is marginally significant with the correct sign for foreign direct investment bilateral inflows. Unlike Brei and von Peter (2018) and Herrmann and Mihaljek (2013), we do not have any evidence showing the significance of distance on bilateral other investment inflows and outflows, perhaps because our bilateral transactions data for other investment flows capture more instruments and includes non-bank direct exposures compared to BIS locational banking data. ${ }^{19}$

\footnotetext{
${ }^{18}$ Aviat and Coeurdacier (2007) find that doubling the distance reduces bilateral portfolio asset holdings, on average, by around $0.09 \%$ of nominal GDP. Given that they have estimated portfolio asset holdings, instead of transactions, the estimated value of $0.02 \%$ of the reporting country GDP $\left(\log (2)^{*}-0.065\right)$ ) shown in Column (3) of Table 5 is a reasonable estimate.

${ }_{19}$ See Brie and von Peter (2018) on the discussion of BIS Locational Banking Statistics. The authors note that the BIS locational statistics do not capture reporting country non-bank transactions to partner non-bank transactions, which is a significant portion of other investment flows of the Balance of Payments Statistics. Consequently, the authors utilized the mirror data technique by merging banking claims and liabilities to show the negative impact of distance-information frictions - on banking flows. In this paper, we use bilateral other investment flows of reporting countries, which include all sectors and all types of instruments including pensions and insurance. Differences in data coverage and definition might explain why the estimated coefficient of other investment inflows and outflows in Table 5 are insignificant, albeit with the correct sign.
} 
For other familiarity variables, the estimates indicate that common legal origin significantly increases bilateral other investment outflows and total gross inflows, largely driven by bilateral portfolio inflows. Colonial ties are significant for bilateral portfolio inflows and outflows, while common language is relevant for other investment outflows and portfolio inflows. However, for the latter two familiarity variables, the coefficients have negative signs which contrast with previous findings. The odd results might be data driven as there are 4 bilateral pairs which report colonial ties, namely Japan-Korea, Japan-Chinese Taipei, KoreaJapan, and New Zealand-Cook Islands. Given that Japan and Korea invest more to other countries outside the East Asia region, this might explain the negative signs of the coefficients. In the case of common language, which usually pertains to English and German in the data set, the negative coefficients might capture portfolio diversification motive, particularly for portfolio inflows.

The estimates also indicate that total, direct, and portfolio bilateral capital outflows are significantly larger if the partner country is a financial centre, while the same is true for foreign direct inflows. These findings suggest that domestic investors tend to invest more on financial centres in line with Warnock and Cleaver (2003). As for bilateral trade, the results offer strong support that bilateral gross capital inflows are significantly larger when trade ties are stronger, such that a one percent increase in bilateral trade increases bilateral gross capital inflows, on average, by around $0.41 \%$ of GDP. The estimated coefficient is very close to the $0.31 \%$ of GDP results of Aviat and Coeurdacier (2007). Unfortunately, having a fixed exchange rate does not exert a significant impact on bilateral transactions.

To check the robustness of the results, we run several sensitivity tests. First, we removed the crisis years of 2008 and 2009, when extreme episodes of capital flows occurred which could bias the overall results (Milesi-Ferretti and Tille, 2011). Second, we estimate the empirical specification without New Zealand due to its long distance from most of the reporting economies. Third, as the financial centre variable acts as a control, we re-estimate the model without the dummy variable for partner financial centre. Finally, we estimate the baseline equation by changing the specifications pertaining to the use of dummy variables. Specifically, instead of using reporter-year and partner-year dummies, we use reporter, partner, and year dummy variables following Portes and Rey (2005). Tables 6a to 6d present the results of these tests. The baseline results hold across various tests, except when we remove the dummy variable for partner financial centre. As shown in Table 6c, bilateral trade is no longer significant for gross capital inflows. This proves the importance of controlling for the financial centre effect given that bilateral transactions with financial centres are largely driven by financial intermediaries and custodians. Moreover, as pointed out by Martin and Rey (2004), financial centres capture market size effects as well as sophistication, which in turn attracts capital flows. These tests validate the baseline results.

The baseline findings offer new insights in the asset trade literature. First, the findings indicate that domestic investors are highly responsive to information frictions and on whether 
their partner country is a financial centre. However, across types of capital flows, it appears that bank flows are less responsive to these factors relative to direct and portfolio outflows. Second, the results also indicate that foreign investors are highly sensitive to trade ties such that bilateral gross capital inflows tend to be larger the stronger the trade ties between country pairs. Taken together, these results suggest that bilateral capital flows are responsive to information frictions, financial centre effect, and trade ties, although their sensitivities to these factors depend on the type of investment and on whether financial transactions are domesticor foreign-driven.

Additional Sensitivity Tests. The varying sensitivities of gross capital inflows and outflows to information frictions and bilateral trade warrant closer inspection. As discussed by Lane and Milesi-Ferretti (2005a) and Aviat and Coeurdacier (2007), distance, a proxy for information frictions, directly and indirectly affects bilateral holdings which positively covary with bilateral transactions. The indirect channel of distance goes through its impact on bilateral trade, which also positively covaries with bilateral holdings, and thereby bilateral flows. To test the extent to which distance directly or indirectly affects bilateral transactions, we run a separate regression where we remove either of the two variables. The results show that distance has become overwhelmingly significant with the correct sign for all kinds of bilateral gross capital inflows and outflows when we remove bilateral trade. Likewise, bilateral trade has become highly significant with the correct sign for all types of bilateral gross capital flows when we remove distance. ${ }^{20}$ These results imply that domestic investors are more sensitive to information frictions when we consider both distance and bilateral trade in the same specification, while foreign investors are, indeed, more responsive to bilateral trade when we consider both factors in the same specification.

We conduct additional sensitivity tests to check to what extent the baseline results will hold if we add or replace some variables and split the sample by grouping, country, and year. The interest for conducting these additional tests lies on how the results will change and not whether the baseline results hold. Of course, if we conduct sample splits we should expect some of the baseline results to change. First, we add Euro Area dummy variable to account for common currency which we expect will reduce transaction costs. The baseline results hold. We also removed the dummy variable for fixed exchange rate in our specification, and the results are the same. Second, adding the European Union dummy variable to account for economic union, does not change the main findings, although bilateral gross capital inflows have become responsive to distance. Next, we replace distance by time difference, sourced from CEPII database. Bilateral trade is now significant for gross capital outflows, along with time difference. This suggests that time difference does not fully capture information frictions as well as bilateral distance as it assume closer proximity with countries in the same time zone as compared to nearby countries but at different time zone. We also split the sample on whether the partner country is an advanced or emerging/developing economy. The results

20 This concurs the marginal R-squared presented in Table 5. 
hold when we have reporter and partner advanced economies, but not if we have advanced and emerging country pairs. This implies that gravity factors remain significant in explaining advance-advance country bilateral transactions, while other factors might be at play for advanced-emerging country bilateral flows. To test the stability of the estimated coefficients, we estimated recursive regressions where we increase the sample size annually while holding the starting date at 2000. The results show that the magnitude and significance of the estimated coefficients stabilized around 2009, implying that the results are fairly stable towards the second half of the sample period. Finally, we estimate Equation (4) on a country-bycountry basis. For the United States, distance and bilateral trade matters for gross capital outflows. For Japan, the higher the distance, the larger the bilateral transactions as it invests more outside the East Asian region. This suggest that for Japan, distance might be capturing other factors apart from information frictions. For Germany, distance is significant with the correct sign for gross capital inflows, while trade is significant for gross capital outflows. For New Zealand, distance is mostly insignificant, while bilateral trade is highly relevant for bilateral gross capital inflows and outflows. These country regressions illustrate substantial cross-country heterogeneity in the sample.

\subsection{Bilateral Capital Flows on Market Size and Transaction Costs}

Baseline Results. Table 7 shows the baseline results assessing the significance of market size and transaction costs on bilateral capital flows. Across types of investments, the empirical specification explains around $10 \%$ to $50 \%$ of the sample variation, suggesting that for some types of bilateral flows the model does not perform very well. However, for most types of capital flows, the model does a fairly good job in accounting for sample variation, particularly for bilateral portfolio flows in line with the model fit of Portes and Rey (2005).

The estimates indicate that the various proxies for direct and indirect transactions costs, such as secure internet connection, control of corruption, and capital account openness, are mostly significant for the reporting or source country. For instance, more financially open source countries invest and receive more bilateral investments from other countries. Source countries with less corruption, on average, have higher bilateral investments across types of capital flows. However, source countries with more secure internet connection usually have less bilateral transactions as it costs more for source country companies to conduct encrypted financial transactions over the internet. In contrast, market size, as proxied by per capita income and financial centre, are consistently significant across types of bilateral flows for the partner or destination country. Specifically, reporting economies tend invest and receive more gross capital flows from partner countries with higher per capita income. Likewise, reporting countries also have more financial transactions if their partner country is a financial centre. These results are aligned with existing studies that find the significance of transaction costs and market size on asset holdings or transactions, such as those from Buch (2005); Choi, Rhee and Oh (2014), Coeurdacier and Martin (2009), Duade and Fratzscher (2008), Hellmanzik and Schmitz (2017), Papaioannou (2009), Portes and Rey (2005), and Portes, 
Rey and Oh (2001), although these papers do not explicitly differentiate transaction costs between source and destination countries. Taken together, these results suggest that bilateral capital flows are more responsive to source country transaction costs; while they are more sensitive to partner country market size.

Sensitivity Tests. We also conduct several robustness checks to validate the results. First, we remove 2008-09 to account for sudden stops and retrenchments of capital flows during the global financial crisis. The results hold i.e. bilateral capital flows are more responsive to source country transaction costs; while they are more sensitive to partner country market size (Table 8a). Second, we remove New Zealand in Table 8b. Again, the baseline results hold. Next, we estimate Equation (5) without the reporter and partner per capita income variable. We confirm that bilateral capital flows are more responsive to source country transaction costs. We also include lagged bank assets in percent of GDP sourced from World Bank's World Development Indicators as a proxy for financial market size. The estimates show that including the bank assets of reporting and partner country do not change the key findings. Following Portes and Rey (2005), replacing per capita income with stock market capitalization in percent of nominal GDP, taken from World Bank's World Development Indicators, leads to the same results, although the estimated coefficients of stock market capitalization is zero, which is expected given the near perfect covariation between transactions and stock market data as shown by Portes and Rey (2005). In the baseline results, we used Chinn and Ito (2006) de jure measure of capital account openness. We rerun the regression model replacing the de jure measure with a de facto measure of financial integration. We use the sum of total external assets and liabilities over nominal GDP from the Lane and Milesi-Ferretti (2017) as our measure of de facto financial integration. Unfortunately, the baseline results do not hold as our de facto measure accounts for total holdings and hence there are multicollinearities in the model. Lastly, we split the specification between reporter and partner market size and transaction costs in Tables $8 \mathrm{c}$ and 8d. Dropping reporter market size and transaction costs, partner per capita income remains highly significant across types of bilateral flows. Removing partner market size and transaction costs, reporter transaction costs remain relevant. Both results indicate that the baseline findings hold when we split the regressors between reporter and partner countries. These tests validate the baseline results.

\section{Concluding Remarks}

This study assesses the significance of information frictions, market size, transaction costs and trade ties on cross-border bilateral transactions. Unlike previous studies which consider bilateral holdings or a specific type of bilateral asset transactions, this paper uses bilateral Financial Account data from the Regional Balance of Payments Statistics of 10 advanced reporting countries. Using bilateral capital flows data allow us to understand the varying sensitivities of domestic and foreign investors across investment types, e.g. direct, portfolio, and other investment, in relation to the covariation between information frictions, market size, transaction costs and trade ties; and gross capital inflows and outflows. Using a 
gravity model specification with reporter-year and partner-year fixed effects, the estimates reveal that bilateral capital flows are responsive to information frictions, financial centre effect, and trade ties. But sensitivities to these gravity forces depend on the type of investment and on whether financial transactions are domestic or foreign-driven. For instance, we find that bilateral capital outflows (assets) are more sensitive to distance and financial centre effect (except for other investment outflows); while bilateral capital inflows (liabilities) are more receptive to bilateral trade ties across all types of capital flows. Controlling for bilateral factors, we then test the relevance of reporter and partner market size and transaction costs on bilateral capital flows. We find bilateral capital flows are more responsive to source country transaction costs such as secure internet connection, control of corruption, and capital account openness. In addition, bilateral transactions appear more sensitive to partner country market size such as per capital income and financial centre effect. These results are new in the asset trade literature as we show varying significance of bilateral factors across different types of investments and investors using bilateral capital flows.

These results have policy implications for emerging economies, particularly those in East and South Asia. As pointed out by Martin and Rey (2004), financial market size attracts more bilateral capital flows as they tend to be deeper and more sophisticated. To the extent that market size overcomes information frictions should serve as a motivation to pursue regional financial cooperation and integration. This is particularly true to regional economies with smaller and less developed financial and capital markets.

This paper demonstrates one application of using bilateral capital flows data in the international macroeconomics. As more economies are now releasing their Regional Balance of Payment Statistics Financial Accounts, this paper takes the first plunge in utilizing the data set to validate cross-border financial market segmentation. Moving forward, using bilateral capital flows data will help uncover new bilateral investment patterns which have been overlooked in the past due to the lack of available data. For instance, bilateral gross capital flows are significantly lower when the reporting country is under a systemic banking crisis compared to when the partner country is undergoing a systemic banking crisis. Such an application reveals cross-border spillovers but that's another story. 


\section{References}

Ahearne, A.; W. Griever and F. Warnock, (2004), "Information Costs and Home Bias: An Analysis of US Holdings of Foreign Equities," Journal of International Economics, 62, pp. 313-336.

Aviat, A. and N. Coeurdacier, (2007), "The Geography of Trade in Goods and Asset Holdings," Journal of International Economics, 71, pp. 22-51.

Baldwin, R. and D. Taglioni, (2007), "Trade Effects of the Euro: A Comparison of Estimators," Journal of Economic Integration, 22(4), pp. 780-818.

Baxter, M. and M. Kouparitsas, (2005), "Determinants of Business Cycle Comovement: A Robust Analysis," Journal of Monetary Economics, 52, pp. 113-157.

Blank, S. and C. Buch, (2007), "The Euro and Cross-Border Baking: Evidence from Bilateral Data," Comparative Economic Studies, 49, pp. 389-410.

Brei, M. and G. von Peter, (2018), "The Distance Effect in Banking and Trade," Journal of International Money and Finance, 81, pp. 116-137.

Buch, C., (2005), "Distance and International Banking," Review of International Economics, 13(4), pp. 787-804.

Chinn, M. and H. Ito, (2006), "What Matters for Financial Development? Capital Controls, Institutions, and Interactions," Journal of Development Economics, 81(1), pp. 163-192.

Choi, C.; D.-E. Rhee and Y. Oh, (2014), "Information and Capital Flows Revisited: The Internet as a Determinant of Transactions in Financial Assets," Economic Modelling, 40, pp. 191198.

Coeurdacier, N., (2009), "Do Trade Cost in Goods Market Lead to Home Bias in Equities," Journal of International Economics, 77, pp. 86-100.

Coeurdacier, N. and P. Martin, (2009), "The Geography of Asset Trade and the Euro: Insiders and Outsiders," Journal of the Japanese and International Economies, 23, pp. 90-113.

di Giovanni, J., (2005), "What Drives Capital Flows? The Case of Cross-Border M\&A Activity and Financial Deepening," Journal of International Economics, 65, pp.127-149.

Duade, C. and M. Fratzscher, (2008), "The Pecking Order of Cross-Border Investment," Journal of International Economics, 74, pp. 94-119.

Galstyan, V., and P. Lane, (2013), "Bilateral Portfolio Dynamics During the Global Financial Crisis," European Economic Review, 57, pp. 63-74.

Galstyan, V.; P. Lane; C. Mehigan and R. Mercado, (2016), "The Holders and Issuers of International Portfolio Securities," Journal of the Japanese and International Economics, 42, pp. $100-108$.

Global Financial Centre Index, (2017).

Head, K. and J. Ries, (2008), "FDI as an Outcome of the Market for Corporate Control: Theory and Evidence," Journal of International Economics, 74, pp. 2-20. 
Hellmanzik, C. and M. Schmitz, (2017), "Taking Gravity Online: The Role of Virtual Proximity in International Finance," Journal of International Money and Finance, 77, pp. 164-179.

Herrmann, S. and D. Mihaljek, (2013), "The Determinants of Cross-Border Bank Flows to Emerging Markets," Economics of Transition, 21(3), pp. 479-508.

International Monetary Fund, Annual Report on Exchange Arrangements and Exchange Restrictions, Accessed: January 2018.

International Monetary Fund, Direction of Trade Statistics, Accessed: January 2018.

International Monetary Fund, World Economic Outlook Database October 2017, Accessed: January 2018.

Kleinert, J.; B. Brueggemann and E. Prieto, (2012), "The Ideal Loan and the Patterns of Crossborder Bank Lending," Technical Report, Karl-Franzens University Graz, Department of Economics.

Lane, P. and G. M. Milesi-Ferretti, (2005a), "International Investment Patterns," The Review of Economics and Statistics, 90(3), pp. 538-549.

Lane, P. and G. M. Milesi-Ferretti, (2005b), "The International Equity Holdings of Euro Area Investors," IIIS Discussion Paper, No. 104.

Lane, P. and G. M. Milesi-Ferretti, (2017), "International Financial Integration in the Aftermath of the Global Financial Crisis," IMF Working Paper, No. 17/115, International Monetary Fund.

Lee, J.-W., (2008), "Patterns and Determinants of Cross-Border Financial Asset Holdings in East Asia," ADB Working Papers on Regional Economic Integration, No. 13, Asian Development Bank.

Lintner, J., (1965), "The Valuation of Risky Assets and the Selection of Risky Investment in Stock Portfolio and Capital Budgets," Review of Economics and Statistics, 47, pp. 103124.

Martin, P. and H. Rey, (2004), "Financial Super-Markets: Size Matters for Asset Trade," Journal of International Economics, 64, pp. 335-361.

Mehigan, C., (2016) "Bilateral Adjustment of Bank Assets: Boom and Bust. Trinity Economics," Papers No. 0616, Trinity College Dublin.

Milesi-Ferretti, G.M. and C. Tille, (2011), "The Great Retrenchment: International Capital Flows During the Global Financial Crisis," Economic Policy, 26(66), pp. 289-346.

Obstfeld, M. and K. Rogoff, (2000), "The Six Major Puzzles in International Macroeconomics: Is there a Common Cause?" NBER Macroeconomics Annual 2000, Vol. 15. National Bureau of Economic Research.

Okawa, Y. and E. van Wincoop, (2012), "Gravity in International Finance," Journal of International Economics, 87, pp. 205-2015.

Papaioannou, E., (2009), "What Drives International Financial Flows? Politics, Institutions and Other Determinants," Journal of Development Economics, 88, pp. 269-281. 
Portes, R. and H. Rey, (2001), "Information and Capital Flows: The Determinants of Transactions in Financial Assets," Journal of International Economics, 45, pp. 783-796.

Portes, R. and H. Rey, (2005), "The Determinants of Cross-Border Equity Flows," Journal of International Economics, 65, pp. 269-296.

Rose, A., (2005), "One Reason Countries Pay Their Debts: Renegotiation and International Trade," Journal of Development Economics, 77, pp.189-206.

Rose, A. and M. Spiegel, (2002), "A Gravity Model of Sovereign Lending: Trade, Default, and Credit," NBER Working Paper, No. 9285, National Bureau of Economic Research.

Sharpe, W., (1964), "Capital Asset Prices: A Theory of Market Equilibrium Under the Condition of Risk," Journal of Finance, 19, pp. 425- 442.

Warnock, F. and C. Cleaver, (2003), "Financial Centres and the Geography of Capital Flows," International Finance, 6 Abstract Capital Flows on Market Size and Transaction Costs

Wei, S.-J. and Y. Wu, (2002), "Negative Alchemy? Corruption, Composition of Capital Flows, and Currency Crises," in Sebastian Edwards (Ed.), Preventing Currency Crises in Emerging Markets. Chicago: University of Chicago Press.

World Bank, World Development Indicators, Accessed: January 2018.

World Bank, World Governance Indicators, Accessed: January 2018. 
FIGURES AND TABLES

Figure 1: Schematic Diagram of Reporting

a) Bilateral Assets Flows

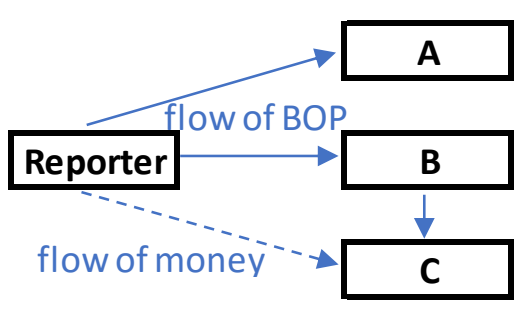

b) Bilateral Liabilities Flows

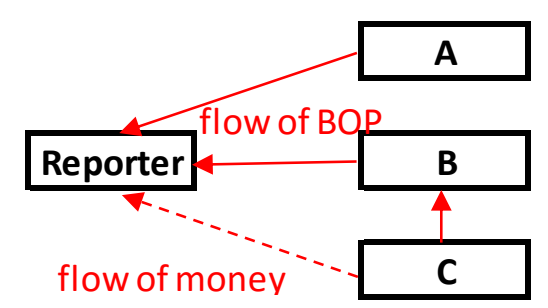


Table 1: Bilateral Capital Flows on Bilateral Holdings

\begin{tabular}{|c|c|c|c|c|c|c|}
\hline & $\begin{array}{l}(1) \\
\text { FDIA }\end{array}$ & $\begin{array}{l}(2) \\
\text { FDIL }\end{array}$ & $\begin{array}{l}\text { (3) } \\
\text { PORTA }\end{array}$ & $\begin{array}{l}(4) \\
\text { PORTL }\end{array}$ & $\begin{array}{l}\text { (5) } \\
\text { OIA }\end{array}$ & $\begin{array}{l}(6) \\
\text { OIL }\end{array}$ \\
\hline Holdings $_{\mathrm{ij}, \mathrm{t}}$ & $\begin{array}{l}0.812 * * * \\
(0.190)\end{array}$ & $\begin{array}{l}0.451 * * \\
(0.205)\end{array}$ & $\begin{array}{l}0.782 * * \\
(0.193)\end{array}$ & $\begin{array}{l}0.549 * * * \\
(0.161)\end{array}$ & $\begin{array}{l}0.796^{* * * *} \\
(0.191)\end{array}$ & $\begin{array}{l}0.779 * * * \\
(0.183)\end{array}$ \\
\hline $\mathrm{R}^{2}$ & 0.507 & 0.468 & 0.495 & 0.491 & 0.531 & 0.500 \\
\hline Obs & 988 & 811 & 2105 & 1851 & 1927 & 1921 \\
\hline \multicolumn{7}{|c|}{$\begin{array}{l}\text { Notes: Dependent variables are annual bilateral capital flows in natural log. Al } \\
\text { specifications include reporter-year and partner-year dummy variables. Holdings in } \\
\text { natural log refer to the bilateral foreign direct investment (inward FDIL and outward FDIA } \\
\text { taken from Coordinated Direct Investment Survey), portfolio assets PORTA anc } \\
\text { liabilities PORTL (taken from Coordinated Portfolio Investment Survey), and othe } \\
\text { investments (outstanding total claims OIA and liabilities OIL taken from Bank fo } \\
\text { International Settlements). Robust standard errors in parentheses. }{ }^{* * *},{ }^{* *} \text {, and }{ }^{*} \text { denote } \\
\text { significance at } 1 \%, 5 \% \text {, and } 10 \% \text { respectively. }\end{array}$} \\
\hline
\end{tabular}


Table 2: Summary of Bilateral Financial Flows

\begin{tabular}{|c|c|c|c|c|c|c|c|c|c|c|}
\hline & 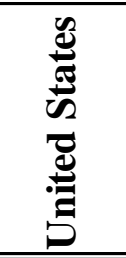 & Uֶّ & 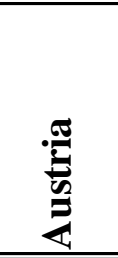 & 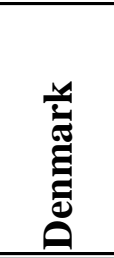 & 胥 & 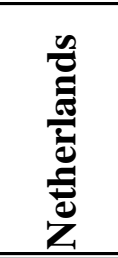 & $\begin{array}{l}\text { 芯 } \\
\text { के }\end{array}$ & 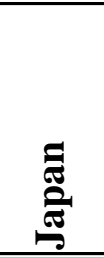 & 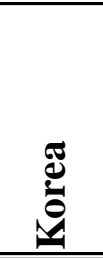 & 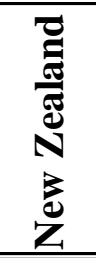 \\
\hline \multicolumn{11}{|l|}{ Foreign Direct Investments } \\
\hline Assets (FDIA) & $\mathrm{TC}$ & $\mathrm{TC}$ & $\mathrm{TC}$ & $\mathrm{TC}$ & $\mathrm{TC}$ & UOIB & $\mathrm{TC}$ & $\mathrm{TC}$ & $\mathrm{TC}$ & TC \\
\hline Liabilities (FDIL) & $\mathrm{TC}$ & $\mathrm{TC}$ & UOIB & $\mathrm{TC}$ & $\mathrm{TC}$ & $\mathrm{TC}$ & $\mathrm{TC}$ & $\mathrm{TC}$ & $\mathrm{TC}$ & TC \\
\hline \multicolumn{11}{|l|}{ Portfolio Investments } \\
\hline Assets (PORTA) & UOIB & $\mathrm{TC}$ & $\mathrm{TC}$ & UOIB & $\mathrm{TC}$ & UOIB & $\mathrm{TC}$ & $\mathrm{TC}$ & $\mathrm{TC}$ & $\mathrm{TC}$ \\
\hline Liabilities (PORTL) & $\mathrm{TC}$ & $\mathrm{TC}$ & (est) & $\mathrm{TC}$ & $\mathrm{TC}$ & (est) & $\mathrm{TC}$ & $\mathrm{TC}$ & $\mathrm{TC}$ & $\mathrm{TC}$ \\
\hline \multicolumn{11}{|l|}{ Financial Derivatives } \\
\hline Assets (DERA) & $x$ & $x$ & $x$ & $\mathrm{TC}$ & $\mathrm{TC}$ & $\mathrm{TC}$ & $x$ & $\mathrm{TC}$ & $\mathrm{TC}$ & $x$ \\
\hline Liabilities (DERL) & $x$ & $x$ & $x$ & $\mathrm{TC}$ & $\mathrm{TC}$ & $x$ & $x$ & $\mathrm{TC}$ & $\mathrm{TC}$ & $x$ \\
\hline \multicolumn{11}{|l|}{ Other Inves tment } \\
\hline Assets (OIA) & $\mathrm{TC}$ & $\mathrm{TC}$ & $\mathrm{TC}$ & $\mathrm{TC}$ & $\mathrm{TC}$ & UOIB & $\mathrm{TC}$ & $\mathrm{TC}$ & $\mathrm{TC}$ & $\mathrm{TC}$ \\
\hline Liabilities (OIL) & $\mathrm{TC}$ & $\mathrm{TC}$ & $\mathrm{TC}$ & $\mathrm{TC}$ & $\mathrm{TC}$ & $\mathrm{TC}$ & $\mathrm{TC}$ & $\mathrm{TC}$ & $\mathrm{TC}$ & $\mathrm{TC}$ \\
\hline Reserve Assets (RESA) & $\mathrm{TC}$ & $\mathrm{TC}$ & $x$ & $\mathrm{TC}$ & $\mathrm{TC}$ & $x$ & $x$ & $x$ & $x$ & $x$ \\
\hline Frequency & Q & Q & Q & M & Q & A & A & Q & A & A \\
\hline Start Year & 2003 & 2000 & 2001 & 2005 & 2000 & 2004 & 2013 & 2000 & 2006 & 2000 \\
\hline End Year & 2016 & 2016 & 2016 & 2016 & 2016 & 2016 & 2016 & 2016 & 2016 & 2016 \\
\hline No. of Counterparty & 21 & 3 & 15 & 36 & 33 & 2 & 7 & 33 & 3 & 30 \\
\hline
\end{tabular}


Table 3: Descriptive Statistics Bilateral Capital Flows

(\% of reporter nominal GDP)

\begin{tabular}{|c|c|c|c|c|c|c|c|c|c|c|}
\hline Capital Flows & Obs & Mean & $\begin{array}{l}\text { Dev. } \\
0-2016\end{array}$ & Min & $\operatorname{Max}$ & Obs & Mean & $\begin{array}{l}\text { Dev. } \\
-2007 \\
\end{array}$ & Min & Max \\
\hline Total Financial Assets & 2,673 & 0.253 & 1.317 & -12.488 & 30.624 & 1,091 & 0.403 & 1.417 & -4.806 & 30.624 \\
\hline Total Financial Liabilities & 2,663 & 0.253 & 2.483 & -18.030 & 44.473 & 1,086 & 0.461 & 2.412 & -10.017 & 44.473 \\
\hline FDI Assets & 2,526 & 0.106 & 0.968 & -18.810 & 28.599 & 1,028 & 0.122 & 0.978 & -2.765 & 28.599 \\
\hline FDI Liabilities & 2,401 & 0.092 & 1.176 & -9.321 & 41.127 & 954 & 0.166 & 1.602 & -3.908 & 41.127 \\
\hline Portfolio Assets & 2,611 & 0.124 & 0.479 & -3.868 & 4.601 & 1,061 & 0.175 & 0.481 & -2.152 & 3.831 \\
\hline Portfolio Liabilities & 2,504 & 0.155 & 2.098 & -18.086 & 23.835 & 1,034 & 0.213 & 1.536 & -9.857 & 15.820 \\
\hline Other Investment Assets & 2,600 & 0.058 & 0.585 & -6.122 & 6.817 & 1,073 & 0.138 & 0.591 & -5.295 & 6.817 \\
\hline Other Investment Liabilities & 2,574 & 0.058 & 0.689 & -5.488 & 6.737 & 1,062 & 0.137 & 0.629 & -2.667 & 5.067 \\
\hline Capital Flows & Obs & $\begin{array}{r}\text { Mean } \\
\\
\end{array}$ & $\begin{array}{l}\text { Dev. } \\
\text { 8-2009 }\end{array}$ & Min & $\operatorname{Max}$ & Obs & Mean & $\begin{array}{l}\text { Dev. } \\
\text {-2016 }\end{array}$ & Min & Max \\
\hline Total Financial Assets & 345 & 0.086 & 1.335 & -8.947 & 10.796 & 1,237 & 0.167 & 1.204 & -12.488 & 24.000 \\
\hline Total Financial Liabilities & 346 & 0.092 & 2.038 & -12.881 & 16.446 & 1,231 & 0.114 & 2.642 & -18.030 & 20.818 \\
\hline FDI Assets & 324 & 0.081 & 0.605 & -7.143 & 5.527 & 1,174 & 0.099 & 1.038 & -18.810 & 24.569 \\
\hline FDI Liabilities & 306 & 0.036 & 0.562 & -8.599 & 2.247 & 1,141 & 0.045 & 0.820 & -9.321 & 15.937 \\
\hline Portfolio Assets & 338 & 0.074 & 0.442 & -1.773 & 4.295 & 1,212 & 0.093 & 0.483 & -3.868 & 4.601 \\
\hline Portfolio Liabilities & 325 & 0.111 & 1.936 & -13.124 & 15.992 & 1,145 & 0.116 & 2.536 & -18.086 & 23.835 \\
\hline Other Investment $A$ & 333 & -0.058 & 0.780 & -6.122 & 3.999 & 1,194 & 0.019 & 0.501 & -5.206 & 4.800 \\
\hline Other Investment Liabilities & 333 & -0.005 & 0.716 & -4.107 & 5.512 & 1,179 & 0.004 & 0.726 & -5.488 & 6.737 \\
\hline
\end{tabular}

Notes: Values are bilateral financial account flows of reporting economies in percent of reporting country nominal GDP. Total financial assets include financial derivatives and official reserves whenever data are available. Total financial liabilities include financial derivatives whenever data are available. Bilateral financial account flows data are sourced from reporting central banks or statistics agencies. 
Table 4: Bilateral Capital Flows, 2016

(in USD billion)

\begin{tabular}{llllllllll}
\hline Reporter & Partner & FINA & FINL & FDIA & FDIL & PORTA & PORTL & OIA & OIL \\
\hline \hline United States & United Kingdom & 87.10 & 47.56 & 38.88 & 49.07 & -31.18 & 39.85 & 79.40 & -41.36 \\
United States & Germany & -4.36 & 66.38 & 5.92 & 14.05 & -16.56 & 54.58 & 6.28 & -2.25 \\
United States & Japan & 71.81 & 182.95 & 2.27 & 33.91 & 35.11 & 88.26 & 34.43 & 60.77 \\
United States & China & 5.97 & -253.66 & 9.47 & 10.34 & -5.94 & -269.91 & 2.44 & 5.91 \\
Germany & United States & 57.31 & -7.44 & 13.35 & 6.30 & 33.70 & -18.65 & 9.46 & 4.90 \\
Germany & United Kingdom & 58.06 & 574.35 & 8.75 & 6.96 & 0.63 & 435.89 & 29.92 & 131.50 \\
Germany & Austria & -4.74 & -5.59 & 0.77 & -3.10 & -4.22 & 1.64 & -1.66 & -4.13 \\
Germany & Japan & 2.89 & 0.03 & 1.02 & 0.17 & -3.92 & 0.87 & 6.38 & -1.01 \\
Japan & United States & 176.41 & -94.41 & 52.21 & 5.76 & 163.70 & -24.40 & 58.03 & 16.42 \\
Japan & United Kingdom & -133.82 & 852.44 & 47.81 & 5.88 & 2.53 & 964.46 & -12.47 & 53.79 \\
Japan & Germany & -1.56 & -7.43 & 2.33 & 0.35 & -5.68 & -9.73 & 11.77 & 10.93 \\
Japan & China & 12.77 & 104.17 & 8.64 & -0.13 & -0.11 & 100.82 & 4.38 & 3.52 \\
\hline
\end{tabular}

Notes: Bilateral financial account flows data are sourced from reporting central banks or statistics agencies. Japan reports around JPY104,554 billion liabilities from the United Kingdom in 2016. The USD964.46 billion was derived by converting quarterly values in US dollar using average exchange rate from the International Financial Statistics. 
Figure 2: United States Bilateral Capital Flows, 2016 (in USD billion)

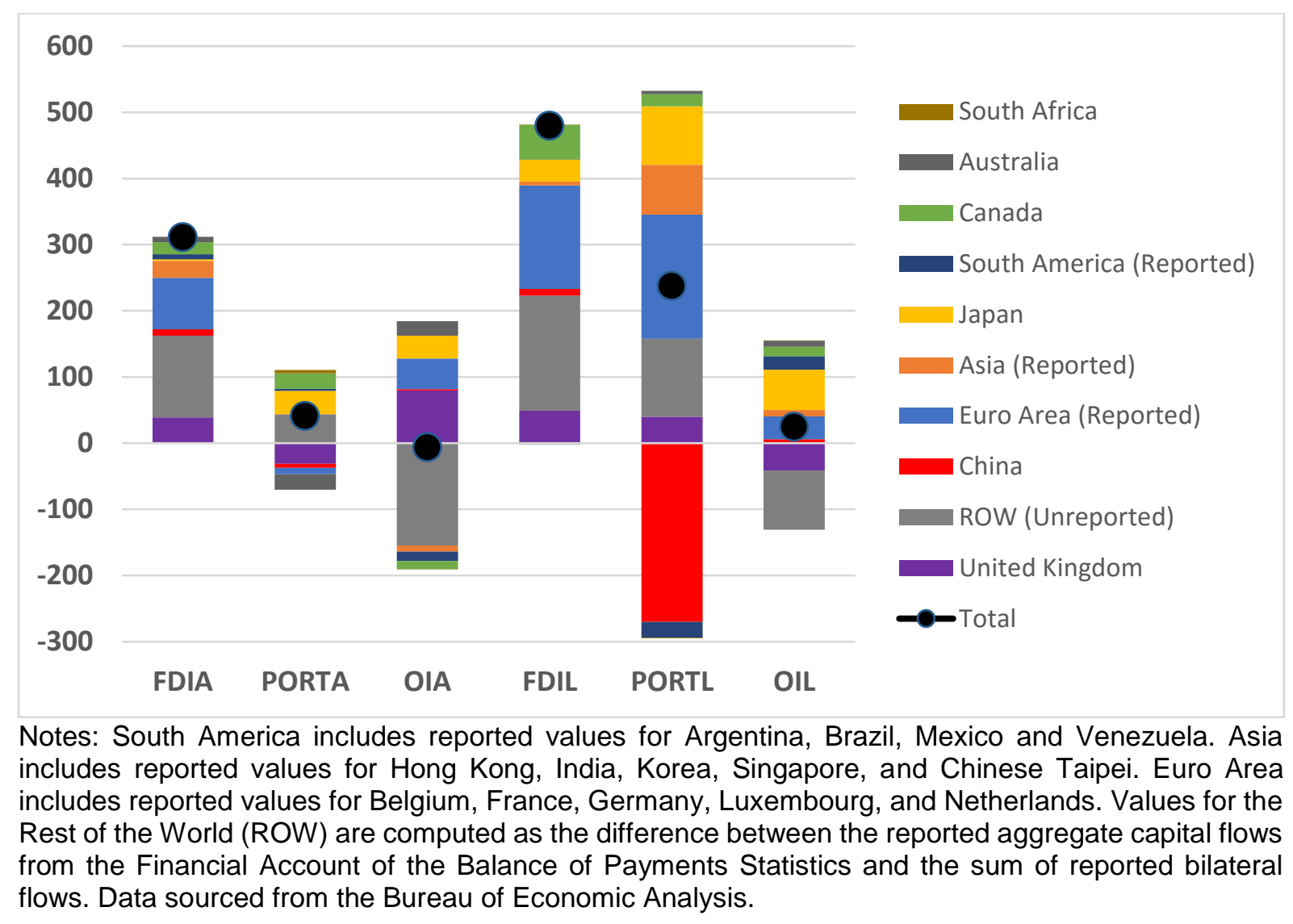


Figure 3: Germany Bilateral Capital Flows, 2016 (in USD billion)

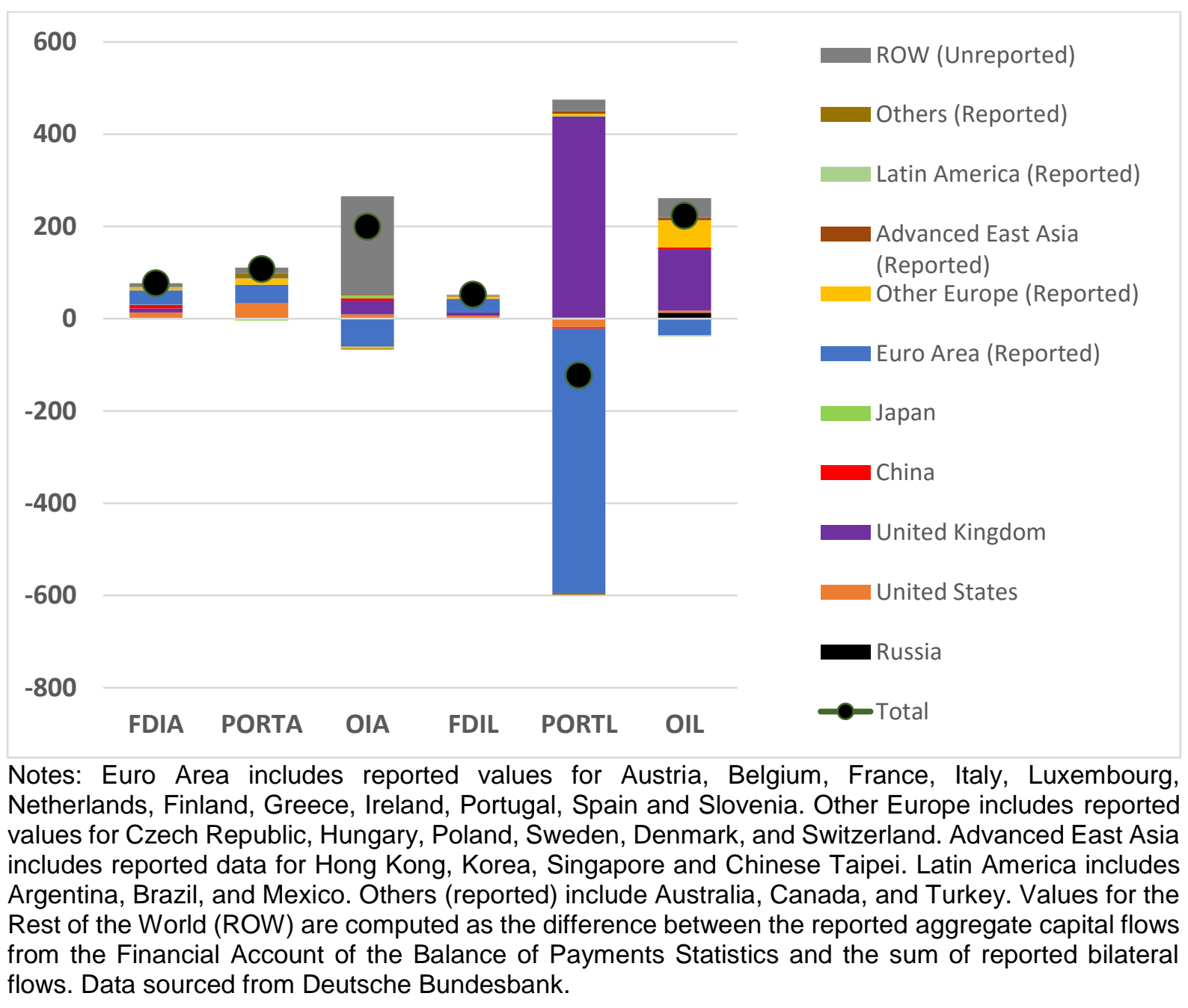


Figure 4: Japan Bilateral Capital Flows, 2016

(in USD billion)

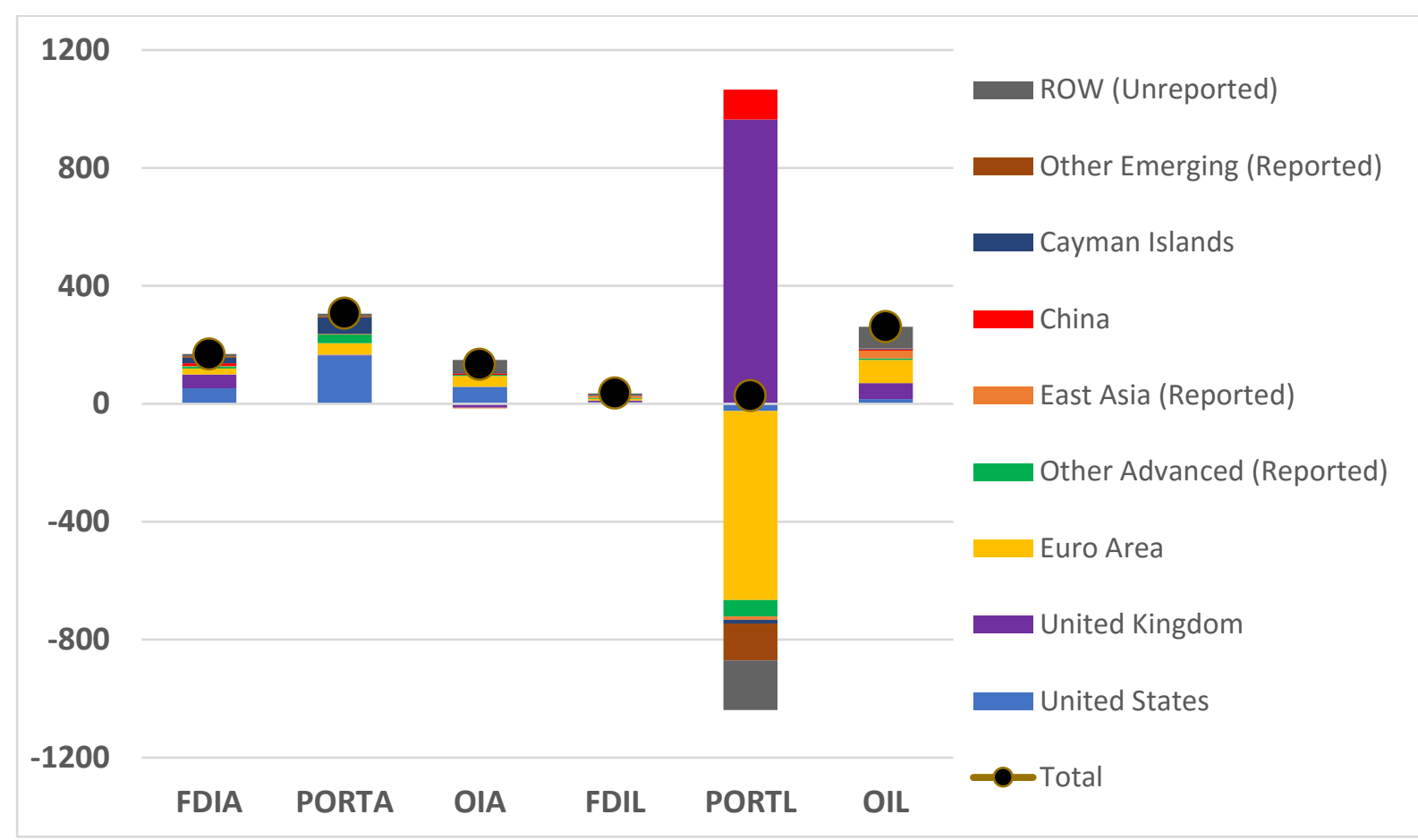

Notes: Euro Area includes Belgium, France, Germany, Italy, Luxembourg, Netherlands, and Spain. Other Advanced (reported) includes Australia, Canada, New Zealand, Sweden, and Switzerland. East Asia (reported) includes Hong Kong, India, Indonesia, Korea, Malaysia, Philippines, Singapore, Chinese Taipei, Thailand, and Vietnam. Other Emerging (reported) includes Brazil, Iran, Mexico, Russia, Saudi Arabia, South Africa, and United Arab Emirates. Values for the Rest of the World (ROW) are computed as the difference between the reported aggregate capital flows from the Financial Account of the Balance of Payments Statistics and the sum of reported bilateral flows. Data sourced from Bank of Japan. 
Figure 5: United States Bilateral Total Assets and Liabilities Flows, 2016 (in USD billion)

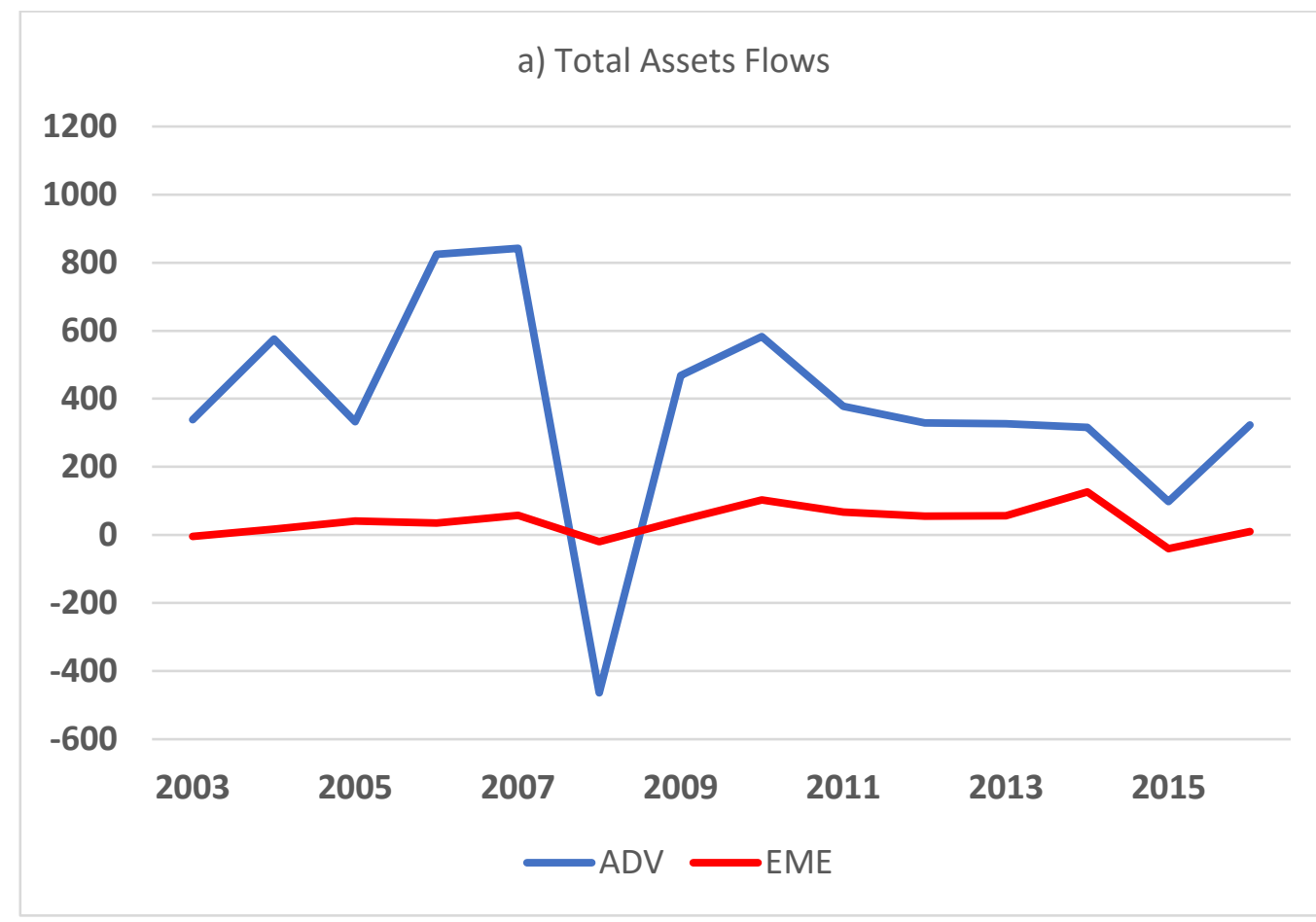

b) Total Liability Flows

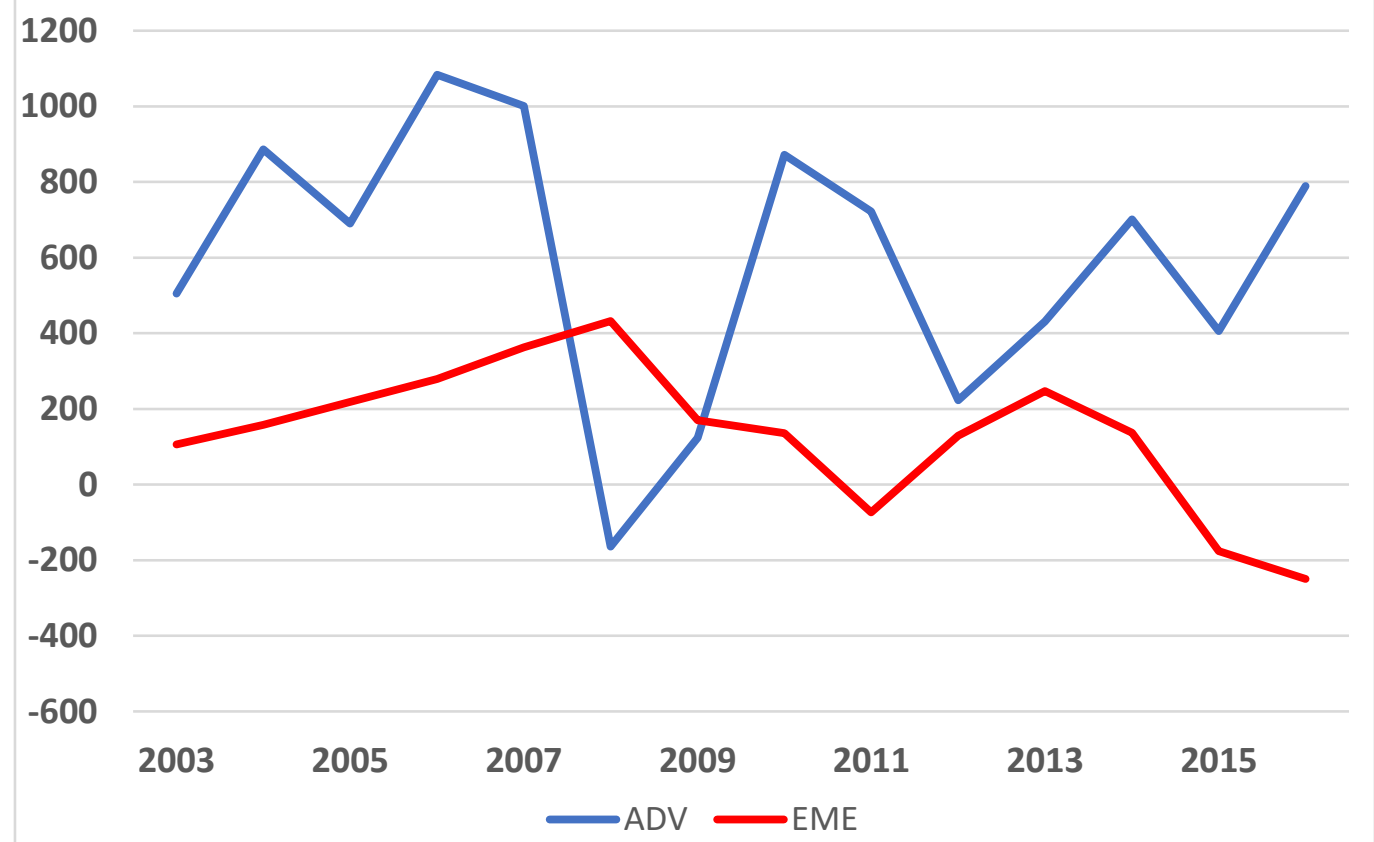

Notes: Advanced economies (ADV) include reported values for Australia, Belgium, Canada, France, Germany, Hong Kong, Italy, Japan, Korea, Luxembourg, Netherlands, Singapore, Chinese Taipei and United Kingdom. Emerging economies (EME) include reported values for Argentina, Brazil, China, India, Mexico, South Africa, and Venezuela. Data sourced from the Bureau of Economic Analysis. 
Figure 6: Germany Bilateral Total Assets and Liabilities Flows, 2016 (in USD billion)

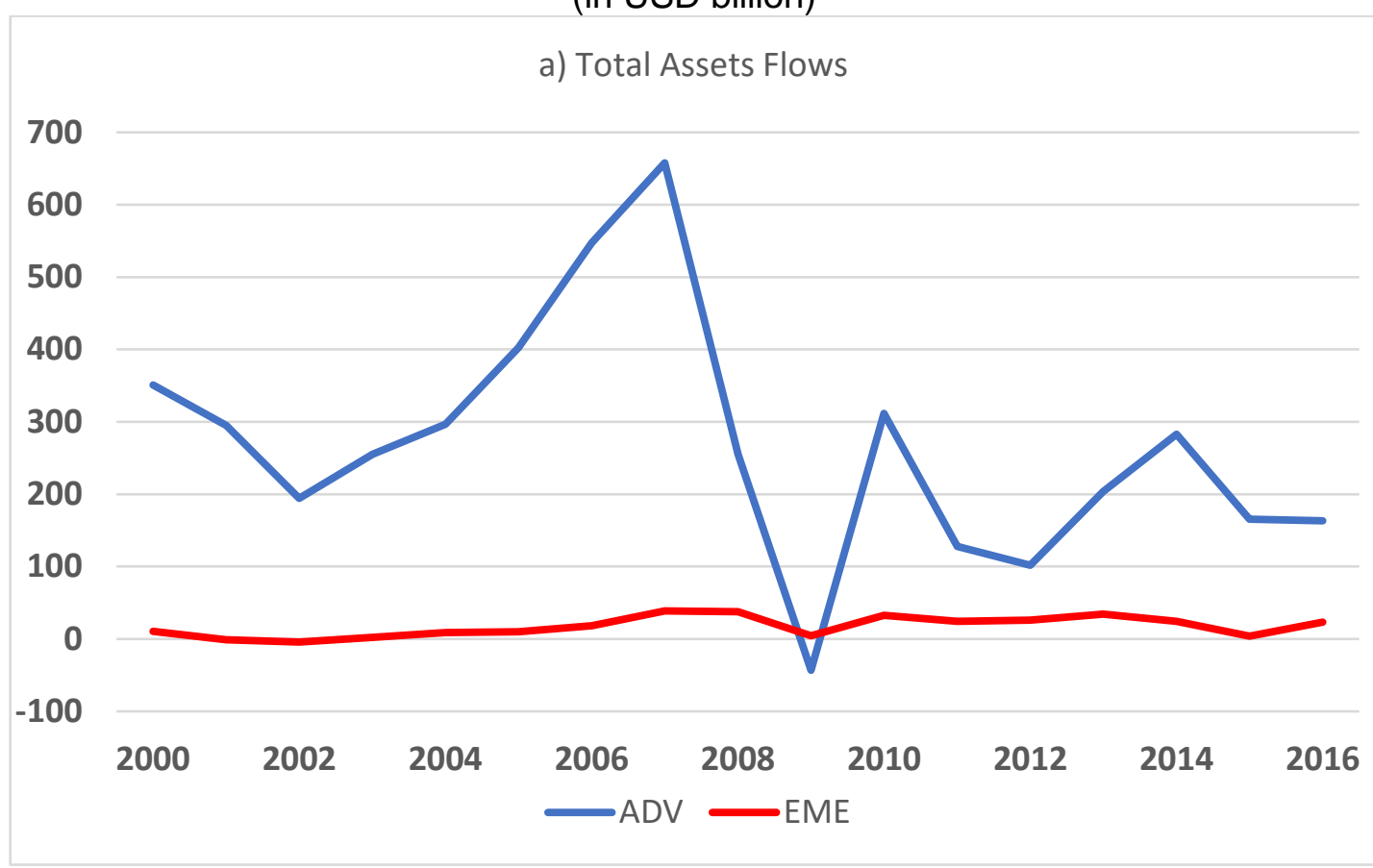

b) Total Liabilities Flows

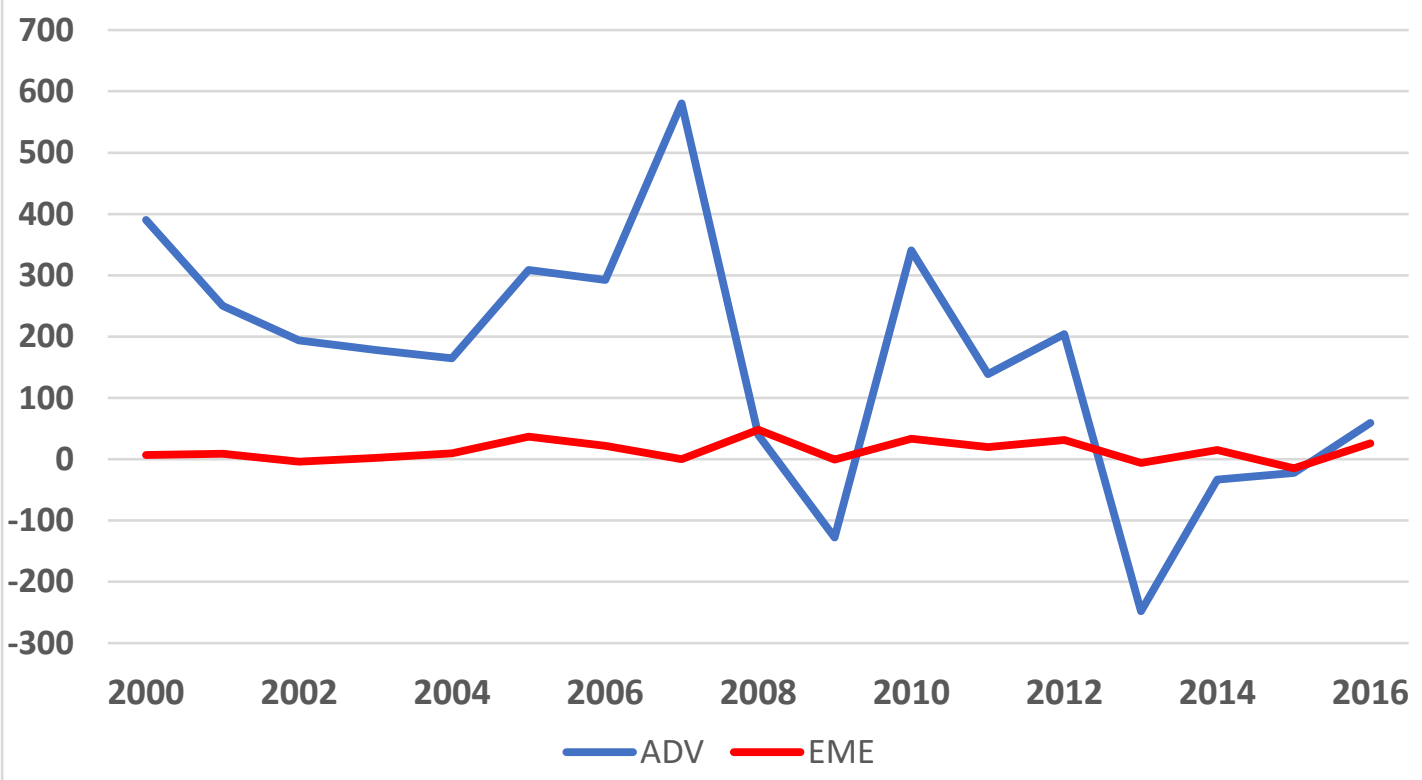

Notes: Advanced economies (ADV) include Australia, Austria, Belgium, Canada, Czech Republic, Denmark, Finland, France, Greece, Hong Kong, Ireland, Italy, Japan, Korea, Luxembourg, Netherlands, Portugal, Singapore, Slovenia, Spain, Sweden, Switzerland, Chinese Taipei, United Kingdom, and United States. Emerging economies (EME) include Argentina, Brazil, China, Hungary, Mexico, Poland, Russia, and Turkey. Data sourced from Deutsche Bundesbank. 
Figure 7: Japan Bilateral Total Assets and Liabilities Flows, 2016 (in USD billion)

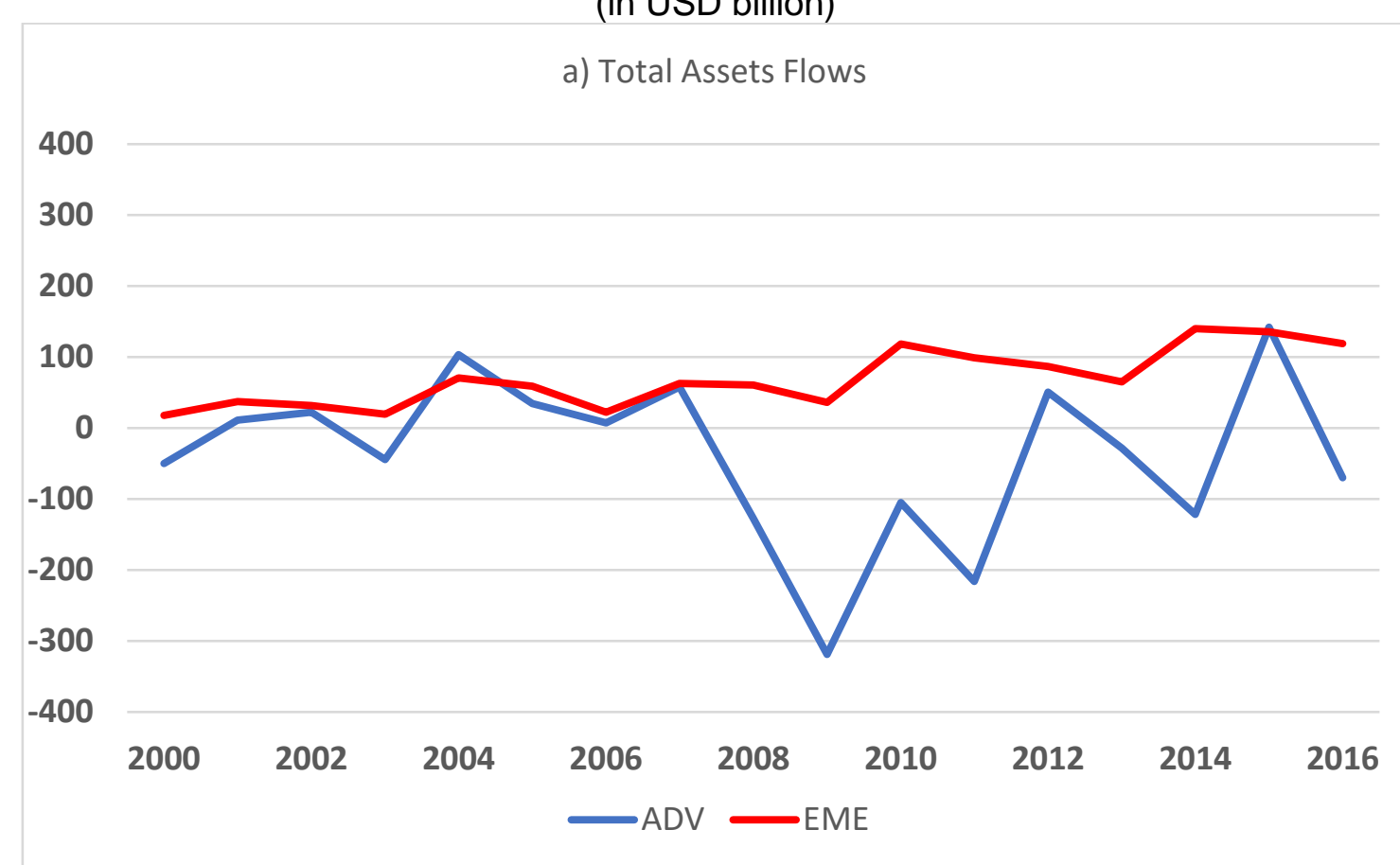

b) Total Liabilities Flows

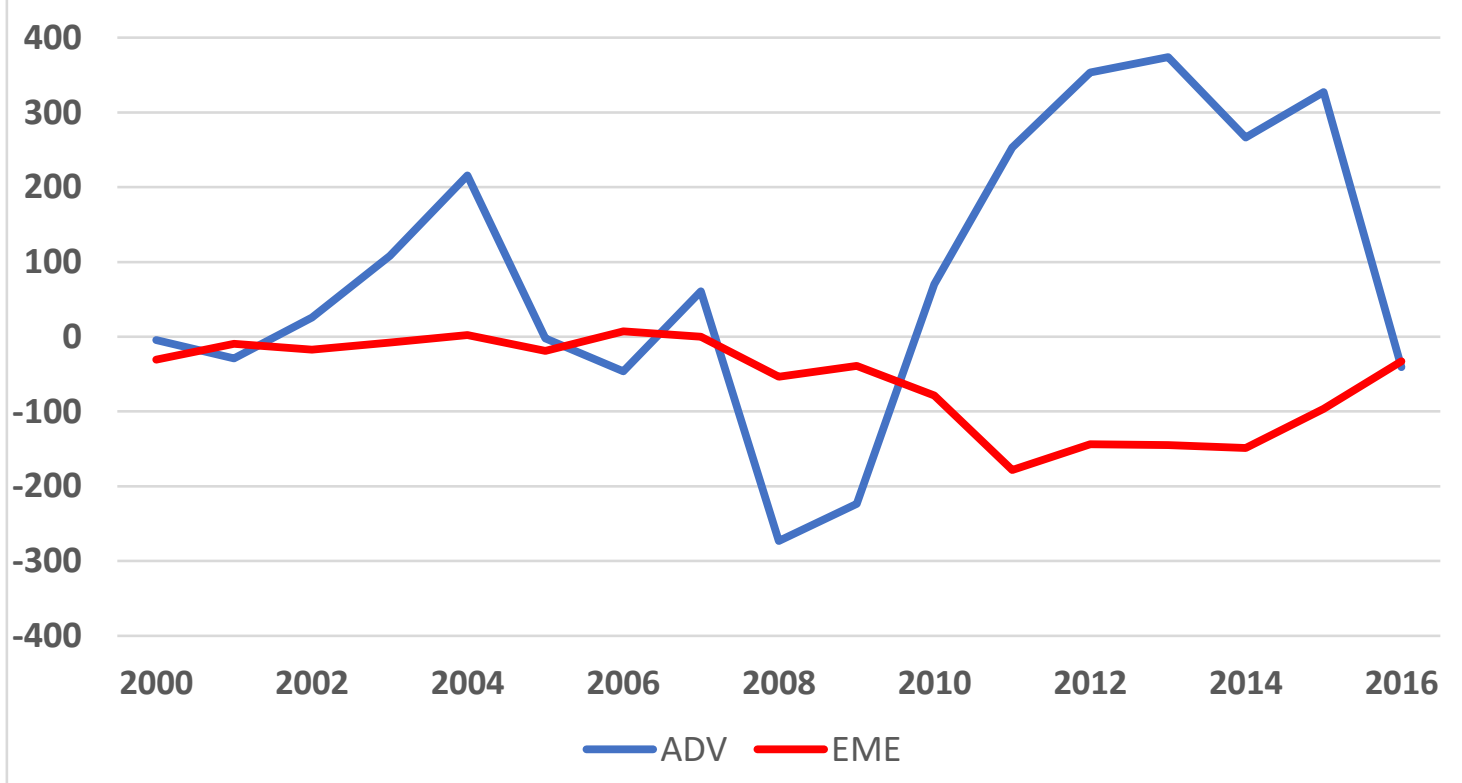

Notes: Advanced economies (ADV) include Australia, Belgium, Canada, France, Germany, Hong Kong, Italy, Korea, Luxembourg, Netherlands, New Zealand, Singapore, Spain, Sweden, Switzerland, Chinese Taipei, United Kingdom, and United States. Emerging economies (EME) include Brazil, Cayman Islands, China, India, Indonesia, Iran, Malaysia, Mexico, Philippines, Russia, Saudi Arabia, South Africa, Thailand, United Arab Emirates, and Vietnam. Data sourced from Bank of Japan. 
Table 5: Bilateral Capital Flows on Gravity Factors

\begin{tabular}{|c|c|c|c|c|c|c|c|c|}
\hline & $\begin{array}{l}\text { (1) } \\
\text { FINA }\end{array}$ & $\begin{array}{l}\text { (2) } \\
\text { FDIA }\end{array}$ & $\begin{array}{l}\text { (3) } \\
\text { PORTA } \\
\end{array}$ & $\begin{array}{l}\text { (4) } \\
\text { OIA } \\
\end{array}$ & $\begin{array}{l}\text { (5) } \\
\text { FINL } \\
\end{array}$ & $\begin{array}{l}\text { (6) } \\
\text { FDIL } \\
\end{array}$ & $\begin{array}{l}\text { (7) } \\
\text { PORTL } \\
\end{array}$ & $\begin{array}{l}\text { (8) } \\
\text { OIL } \\
\end{array}$ \\
\hline Distance $_{\mathrm{ij}}$ & $\begin{array}{l}-0.168 * * \\
(0.056)\end{array}$ & $\begin{array}{l}-0.048^{*} \\
(0.021)\end{array}$ & $\begin{array}{l}-0.065^{* *} \\
(0.022)\end{array}$ & $\begin{array}{l}-0.040 \\
(0.040)\end{array}$ & $\begin{array}{l}-0.261 \\
(0.144)\end{array}$ & $\begin{array}{l}-0.071^{*} \\
(0.031)\end{array}$ & $\begin{array}{l}-0.215 \\
(0.141)\end{array}$ & $\begin{array}{l}-0.009 \\
(0.041)\end{array}$ \\
\hline Colony $_{\mathrm{ij}}$ & $\begin{array}{l}-0.146 \\
(0.172)\end{array}$ & $\begin{array}{l}-0.029 \\
(0.131)\end{array}$ & $\begin{array}{l}-0.128^{*} \\
(0.062)\end{array}$ & $\begin{array}{l}-0.167 \\
(0.088)\end{array}$ & $\begin{array}{l}-0.935^{* *} \\
(0.312)\end{array}$ & $\begin{array}{l}0.046 \\
(0.163)\end{array}$ & $\begin{array}{l}-1.168 * * * \\
(0.266)\end{array}$ & $\begin{array}{l}-0.112 \\
(0.110)\end{array}$ \\
\hline Legal $_{i j}$ & $\begin{array}{l}0.155 \\
(0.097)\end{array}$ & $\begin{array}{l}0.056 \\
(0.061)\end{array}$ & $\begin{array}{l}-0.015 \\
(0.040)\end{array}$ & $\begin{array}{l}0.143^{*} \\
(0.067)\end{array}$ & $\begin{array}{l}1.648 * * * \\
(0.298)\end{array}$ & $\begin{array}{l}0.040 \\
(0.067)\end{array}$ & $\begin{array}{l}1.729 * * * \\
(0.324)\end{array}$ & $\begin{array}{l}0.029 \\
(0.081)\end{array}$ \\
\hline Language $_{i j}$ & $\begin{array}{l}-0.223 \\
(0.137)\end{array}$ & $\begin{array}{l}-0.150 \\
(0.098)\end{array}$ & $\begin{array}{l}-0.004 \\
(0.055)\end{array}$ & $\begin{array}{l}-0.183^{*} \\
(0.083)\end{array}$ & $\begin{array}{l}-3.826 * * * \\
(0.514)\end{array}$ & $\begin{array}{l}-0.092 \\
(0.112)\end{array}$ & $\begin{array}{l}-4.053 * * * \\
(0.548)\end{array}$ & $\begin{array}{l}-0.033 \\
(0.093)\end{array}$ \\
\hline Financial Centre $_{j}$ & $\begin{array}{l}3.298 * * \\
(1.224)\end{array}$ & $\begin{array}{l}1.067 * * \\
(0.355)\end{array}$ & $\begin{array}{l}1.475^{* *} \\
(0.452)\end{array}$ & $\begin{array}{l}1.035 \\
(0.724)\end{array}$ & $\begin{array}{l}1.826 \\
(1.794)\end{array}$ & $\begin{array}{l}0.885^{*} \\
(0.357)\end{array}$ & $\begin{array}{l}0.378 \\
(1.145)\end{array}$ & $\begin{array}{l}0.847 \\
(0.566)\end{array}$ \\
\hline Trade $_{\mathrm{ij}, \mathrm{t}-1}$ & $\begin{array}{l}0.140 * * * \\
(0.034)\end{array}$ & $\begin{array}{l}0.065^{* * * *} \\
(0.012)\end{array}$ & $\begin{array}{l}0.027 \\
(0.016)\end{array}$ & $\begin{array}{l}0.045 \\
(0.025)\end{array}$ & $\begin{array}{l}0.407 * * * \\
(0.043)\end{array}$ & $\begin{array}{l}0.053^{* *} \\
(0.020)\end{array}$ & $\begin{array}{l}0.271 * * * \\
(0.033)\end{array}$ & $\begin{array}{l}0.079 * * * * \\
(0.014)\end{array}$ \\
\hline Fixed $\mathrm{FX}_{\mathrm{ij}, \mathrm{t}}$ & $\begin{array}{l}-0.165 \\
(0.131)\end{array}$ & $\begin{array}{l}-0.110^{*} \\
(0.053)\end{array}$ & $\begin{array}{l}0.078 \\
(0.047)\end{array}$ & $\begin{array}{l}0.045 \\
(0.080)\end{array}$ & $\begin{array}{l}-0.455 \\
(0.356)\end{array}$ & $\begin{array}{l}-0.152 \\
(0.084)\end{array}$ & $\begin{array}{l}0.059 \\
(0.345)\end{array}$ & $\begin{array}{l}0.008 \\
(0.098)\end{array}$ \\
\hline $\mathrm{R}^{2}$ & 0.569 & 0.610 & 0.551 & 0.423 & 0.426 & 0.506 & 0.385 & 0.429 \\
\hline Marginal $R^{2}$ (adding distance) & 0.028 & 0.008 & 0.020 & 0.009 & 0.027 & 0.006 & 0.020 & 0.006 \\
\hline Marginal $\mathrm{R}^{2}$ (adding trade) & 0.057 & 0.024 & 0.021 & 0.022 & 0.087 & 0.011 & 0.056 & 0.040 \\
\hline Obs & 2657 & 2506 & 2593 & 2585 & 2646 & 2393 & 2494 & 2559 \\
\hline $\begin{array}{l}\text { Notes: Dependent variable } \\
\text { specifications include repor } \\
\text { is computed as } 1-\mathrm{RSS} / \mathrm{RS} \\
\text { with distance but without tra } \\
\text { without distance and trade. } \\
\text { residual sum of squares in } \\
\text { residual sum of squares in a }\end{array}$ & $\begin{array}{l}\text { r-yea } \\
\text { wher } \\
\text { e, wh } \\
\text { largin }\end{array}$ & $\begin{array}{l}\mathrm{SS} \text { is } \\
\mathrm{SS}^{c}\end{array}$ & $\begin{array}{l}\text { resic } \\
\text { res } \\
\text { trad } \\
\text { tion }\end{array}$ & $\begin{array}{l}\text { flo } \\
\text { imy } \\
\text { sum } \\
\text { sun } \\
\text { com } \\
\text { trao }\end{array}$ & $\begin{array}{l}\% \quad 0 \\
\text { les. } 1\end{array}$ & $\begin{array}{l}\text { orti } \\
\text { inal } \\
\text { re }\end{array}$ & $\begin{array}{l}\text { ountry } \\
\text { adding } \\
\text { on sp } \\
\text { ion sp } \\
\text { here } \\
\text { hile } \mathrm{F}\end{array}$ & $\begin{array}{l}\text { DP. All } \\
\text { istance) } \\
\text { ification } \\
\text { ification } \\
S \text { is the } \\
S^{c} \text { is the }\end{array}$ \\
\hline
\end{tabular}


Table 6A: Bilateral Capital Flows on Gravity Factors (without 2008 and 2009)

\begin{tabular}{|c|c|c|c|c|c|c|c|c|}
\hline & $\begin{array}{l}\text { (1) } \\
\text { FINA }\end{array}$ & $\begin{array}{l}\text { (2) } \\
\text { FDIA }\end{array}$ & $\begin{array}{l}\text { (3) } \\
\text { PORTA }\end{array}$ & $\begin{array}{l}\text { (4) } \\
\text { OIA }\end{array}$ & $\begin{array}{l}\text { (5) } \\
\text { FINL }\end{array}$ & $\begin{array}{l}\text { (6) } \\
\text { FDIL }\end{array}$ & $\begin{array}{l}\text { (7) } \\
\text { PORTL }\end{array}$ & $\begin{array}{l}\text { (8) } \\
\text { OIL }\end{array}$ \\
\hline Distance $_{i j}$ & $\begin{array}{l}-0.181 * * \\
(0.058)\end{array}$ & $\begin{array}{l}-0.042 \\
(0.023)\end{array}$ & $\begin{array}{l}-0.060 * * \\
(0.022)\end{array}$ & $\begin{array}{l}-0.078 \\
(0.042)\end{array}$ & $\begin{array}{l}-0.272 \\
(0.156)\end{array}$ & $\begin{array}{l}-0.080^{*} \\
(0.036)\end{array}$ & $\begin{array}{l}-0.223 \\
(0.152)\end{array}$ & $\begin{array}{l}-0.012 \\
(0.044)\end{array}$ \\
\hline Colony $_{\mathrm{ij}}$ & $\begin{array}{l}-0.200 \\
(0.180)\end{array}$ & $\begin{array}{l}0.021 \\
(0.146)\end{array}$ & $\begin{array}{l}-0.152^{*} \\
(0.063)\end{array}$ & $\begin{array}{l}-0.255^{* *} \\
(0.093)\end{array}$ & $\begin{array}{l}-0.989 * * \\
(0.339)\end{array}$ & $\begin{array}{l}0.075 \\
(0.185)\end{array}$ & $\begin{array}{l}-1.197 * * * \\
(0.284)\end{array}$ & $\begin{array}{l}-0.164 \\
(0.118)\end{array}$ \\
\hline Legal $_{i j}$ & $\begin{array}{l}0.160 \\
(0.100)\end{array}$ & $\begin{array}{l}0.036 \\
(0.066)\end{array}$ & $\begin{array}{l}-0.015 \\
(0.042)\end{array}$ & $\begin{array}{l}0.188^{* *} \\
(0.071)\end{array}$ & $\begin{array}{l}1.692 * * * \\
(0.324)\end{array}$ & $\begin{array}{l}0.062 \\
(0.076)\end{array}$ & $\begin{array}{l}1.720 * * * \\
(0.352)\end{array}$ & $\begin{array}{l}0.071 \\
(0.087)\end{array}$ \\
\hline Language $_{i j}$ & $\begin{array}{l}-0.256 \\
(0.146)\end{array}$ & $\begin{array}{l}-0.143 \\
(0.110)\end{array}$ & $\begin{array}{l}0.010 \\
(0.060)\end{array}$ & $\begin{array}{l}-0.278^{* *} \\
(0.086)\end{array}$ & $\begin{array}{l}-3.851 * * * \\
(0.557)\end{array}$ & $\begin{array}{l}-0.139 \\
(0.127)\end{array}$ & $\begin{array}{l}-4.002^{* * * *} \\
(0.591)\end{array}$ & $\begin{array}{l}-0.078 \\
(0.101)\end{array}$ \\
\hline Financial Centre $_{j}$ & $\begin{array}{l}3.266^{* *} \\
(1.219)\end{array}$ & $\begin{array}{l}1.052^{* * *} \\
(0.355)\end{array}$ & $\begin{array}{l}1.415^{* * *} \\
(0.427)\end{array}$ & $\begin{array}{l}1.102 \\
(0.742)\end{array}$ & $\begin{array}{l}1.772 \\
(1.798)\end{array}$ & $\begin{array}{l}0.902 * \\
(0.360)\end{array}$ & $\begin{array}{l}0.352 \\
(1.145)\end{array}$ & $\begin{array}{l}0.814 \\
(0.576)\end{array}$ \\
\hline $\operatorname{Trade}_{\mathrm{ij}, \mathrm{t}-1}$ & $\begin{array}{l}0.155^{* * * *} \\
(0.035)\end{array}$ & $\begin{array}{l}0.067 * * * \\
(0.013)\end{array}$ & $\begin{array}{l}0.037^{*} \\
(0.017)\end{array}$ & $\begin{array}{l}0.049 \\
(0.029)\end{array}$ & $\begin{array}{l}0.418 * * * \\
(0.047)\end{array}$ & $\begin{array}{l}0.055^{*} \\
(0.023)\end{array}$ & $\begin{array}{l}0.274 * * * \\
(0.036)\end{array}$ & $\begin{array}{l}0.086 \text { *** } \\
(0.016)\end{array}$ \\
\hline Fixed $\mathrm{FX}_{\mathrm{ij}, \mathrm{t}}$ & $\begin{array}{l}-0.263 \\
(0.135)\end{array}$ & $\begin{array}{l}-0.108 \\
(0.058)\end{array}$ & $\begin{array}{l}0.042 \\
(0.049)\end{array}$ & $\begin{array}{l}-0.020 \\
(0.082)\end{array}$ & $\begin{array}{l}-0.441 \\
(0.390)\end{array}$ & $\begin{array}{l}-0.171 \\
(0.096)\end{array}$ & $\begin{array}{l}0.094 \\
(0.377)\end{array}$ & $\begin{array}{l}0.022 \\
(0.105)\end{array}$ \\
\hline $\begin{array}{l}\mathrm{R}^{2} \\
\text { Obs }\end{array}$ & $\begin{array}{l}0.588 \\
2313\end{array}$ & $\begin{array}{l}0.609 \\
2184\end{array}$ & $\begin{array}{l}0.578 \\
2256\end{array}$ & $\begin{array}{l}0.395 \\
2254\end{array}$ & $\begin{array}{l}0.434 \\
2302\end{array}$ & $\begin{array}{l}0.508 \\
2088\end{array}$ & $\begin{array}{l}0.386 \\
2169\end{array}$ & $\begin{array}{l}0.429 \\
2226\end{array}$ \\
\hline
\end{tabular}


Table 6B: Bilateral Capital Flows on Gravity Factors (without New Zealand)

\begin{tabular}{|c|c|c|c|c|c|c|c|c|}
\hline & $\begin{array}{l}\text { (1) } \\
\text { FINA } \\
\end{array}$ & $\begin{array}{l}(2) \\
\text { FDIA }\end{array}$ & $\begin{array}{l}\text { (3) } \\
\text { PORTA }\end{array}$ & $\begin{array}{l}(4) \\
\text { OIA }\end{array}$ & $\begin{array}{l}\mathbf{5}) \\
\text { FINL } \\
\end{array}$ & $\begin{array}{l}\text { (6) } \\
\text { FDIL } \\
\end{array}$ & $\begin{array}{l}\text { (7) } \\
\text { PORTL }\end{array}$ & $\begin{array}{l}8) \\
\text { OIL }\end{array}$ \\
\hline Distance $_{i j}$ & $\begin{array}{l}-0.222 * * * \\
(0.064)\end{array}$ & $\begin{array}{l}-0.063 * * \\
(0.021)\end{array}$ & $\begin{array}{l}-0.082 * * \\
(0.026)\end{array}$ & $\begin{array}{l}-0.061 \\
(0.043)\end{array}$ & $\begin{array}{l}-0.102 \\
(0.177)\end{array}$ & $\begin{array}{l}-0.036 \\
(0.033)\end{array}$ & $\begin{array}{l}-0.050 \\
(0.170)\end{array}$ & $\begin{array}{l}-0.005 \\
(0.043)\end{array}$ \\
\hline Colony $_{\mathrm{ij}}$ & $\begin{array}{l}-0.297 \\
(0.220)\end{array}$ & $\begin{array}{l}-0.065 \\
(0.167)\end{array}$ & $\begin{array}{l}-0.205 * * \\
(0.077)\end{array}$ & $\begin{array}{l}-0.239 * \\
(0.106)\end{array}$ & $\begin{array}{l}-0.450 \\
(0.391)\end{array}$ & $\begin{array}{l}0.138 \\
(0.204)\end{array}$ & $\begin{array}{l}-0.708^{*} \\
(0.307)\end{array}$ & $\begin{array}{l}-0.095 \\
(0.123)\end{array}$ \\
\hline Legal $_{i j}$ & $\begin{array}{l}0.377 * \\
(0.149)\end{array}$ & $\begin{array}{l}0.116 \\
(0.092)\end{array}$ & $\begin{array}{l}0.034 \\
(0.058)\end{array}$ & $\begin{array}{l}0.210^{*} \\
(0.092)\end{array}$ & $\begin{array}{l}1.934 * * * \\
(0.391)\end{array}$ & $\begin{array}{l}0.070 \\
(0.095)\end{array}$ & $\begin{array}{l}1.785^{* * *} \\
(0.363)\end{array}$ & $\begin{array}{l}0.043 \\
(0.111)\end{array}$ \\
\hline Language $_{i j}$ & $\begin{array}{l}-0.240 \\
(0.181)\end{array}$ & $\begin{array}{l}-0.124 \\
(0.121)\end{array}$ & $\begin{array}{l}0.042 \\
(0.069)\end{array}$ & $\begin{array}{l}-0.195^{*} \\
(0.096)\end{array}$ & $\begin{array}{l}-4.768 * * * \\
(0.667)\end{array}$ & $\begin{array}{l}-0.070 \\
(0.137)\end{array}$ & $\begin{array}{l}-4.779 * * * \\
(0.654)\end{array}$ & $\begin{array}{l}-0.025 \\
(0.114)\end{array}$ \\
\hline Financial Centre $_{j}$ & $\begin{array}{l}3.127 \\
(1.649)\end{array}$ & $\begin{array}{l}1.220^{* *} \\
(0.460)\end{array}$ & $\begin{array}{l}1.639 * * \\
(0.625)\end{array}$ & $\begin{array}{l}0.539 \\
(0.676)\end{array}$ & $\begin{array}{l}-0.085 \\
(0.942)\end{array}$ & $\begin{array}{l}0.850 \\
(0.480)\end{array}$ & $\begin{array}{l}-1.042 \\
(0.684)\end{array}$ & $\begin{array}{l}0.414 \\
(0.442)\end{array}$ \\
\hline Trade $_{\mathrm{ij}, \mathrm{t}-1}$ & $\begin{array}{l}0.133^{* * *} \\
(0.036)\end{array}$ & $\begin{array}{l}0.061 \text { *** } \\
(0.013)\end{array}$ & $\begin{array}{l}0.024 \\
(0.017)\end{array}$ & $\begin{array}{l}0.045 \\
(0.025)\end{array}$ & $\begin{array}{l}0.453^{* * *} \\
(0.051)\end{array}$ & $\begin{array}{l}0.048^{*} \\
(0.022)\end{array}$ & $\begin{array}{l}0.332^{* * * *} \\
(0.040)\end{array}$ & $\begin{array}{l}0.074 * * * \\
(0.016)\end{array}$ \\
\hline Fixed $\mathrm{FX}_{\mathrm{ij}, \mathrm{t}}$ & $\begin{array}{l}-0.284 * \\
(0.143)\end{array}$ & $\begin{array}{l}-0.112 \\
(0.059)\end{array}$ & $\begin{array}{l}0.056 \\
(0.054)\end{array}$ & $\begin{array}{l}0.003 \\
(0.083)\end{array}$ & $\begin{array}{l}0.060 \\
(0.425)\end{array}$ & $\begin{array}{l}-0.114 \\
(0.091)\end{array}$ & $\begin{array}{l}0.466 \\
(0.415)\end{array}$ & $\begin{array}{l}-0.002 \\
(0.105)\end{array}$ \\
\hline $\mathrm{R}^{2}$ & $\begin{array}{l}0.611 \\
2210\end{array}$ & $\begin{array}{l}0.622 \\
2188\end{array}$ & $\begin{array}{l}0.594 \\
2193\end{array}$ & $\begin{array}{l}0.497 \\
2202\end{array}$ & $\begin{array}{l}0.460 \\
2210\end{array}$ & $\begin{array}{l}0.523 \\
2061\end{array}$ & $\begin{array}{l}0.419 \\
2194\end{array}$ & $\begin{array}{l}0.464 \\
2205\end{array}$ \\
\hline
\end{tabular}

Notes: Dependent variables are annual bilateral capital flows in \% of reporting country GDP. All specifications include reporter-year and partner-year dummy variables. Robust standard errors in parentheses. ${ }^{* * *},{ }^{* *}$, and ${ }^{*}$ denote significance at $1 \%, 5 \%$, and $10 \%$ respectively. 
Table 6C: Bilateral Capital Flows on Gravity Factors

(without dummy variable for partner financial centre)

\begin{tabular}{|c|c|c|c|c|c|c|c|c|}
\hline & $\begin{array}{l}\text { (1) } \\
\text { FINA }\end{array}$ & $\begin{array}{l}\text { (2) } \\
\text { FDIA } \\
\end{array}$ & $\begin{array}{l}\text { (3) } \\
\text { PORTA }\end{array}$ & $\begin{array}{l}\text { (4) } \\
\text { OIA }\end{array}$ & $\begin{array}{l}\text { (5) } \\
\text { FINL } \\
\end{array}$ & $\begin{array}{l}\text { (6) } \\
\text { FDIL } \\
\end{array}$ & $\begin{array}{l}\text { (7) } \\
\text { PORTL }\end{array}$ & $\begin{array}{l}\text { (8) } \\
\text { OIL } \\
\end{array}$ \\
\hline Distance $_{i j}$ & $\begin{array}{l}-0.134 * \\
(0.061)\end{array}$ & $\begin{array}{l}-0.014 \\
(0.027)\end{array}$ & $\begin{array}{l}-0.091 * * \\
(0.028)\end{array}$ & $\begin{array}{l}-0.013 \\
(0.039)\end{array}$ & $\begin{array}{l}0.150 \\
(0.153)\end{array}$ & $\begin{array}{l}-0.020 \\
(0.055)\end{array}$ & $\begin{array}{l}0.095 \\
(0.162)\end{array}$ & $\begin{array}{l}0.016 \\
(0.055)\end{array}$ \\
\hline Colony $_{\mathrm{ij}}$ & $\begin{array}{l}-0.321^{*} \\
(0.152)\end{array}$ & $\begin{array}{l}-0.012 \\
(0.068)\end{array}$ & $\begin{array}{l}-0.159^{*} \\
(0.064)\end{array}$ & $\begin{array}{l}-0.094 \\
(0.100)\end{array}$ & $\begin{array}{l}-0.726 \\
(0.474)\end{array}$ & $\begin{array}{l}0.028 \\
(0.119)\end{array}$ & $\begin{array}{l}-0.921 \\
(0.469)\end{array}$ & $\begin{array}{l}0.024 \\
(0.159)\end{array}$ \\
\hline Legal $_{i j}$ & $\begin{array}{l}0.114 \\
(0.088)\end{array}$ & $\begin{array}{l}0.018 \\
(0.038)\end{array}$ & $\begin{array}{l}-0.015 \\
(0.038)\end{array}$ & $\begin{array}{l}0.110 \\
(0.064)\end{array}$ & $\begin{array}{l}2.332 * * * \\
(0.460)\end{array}$ & $\begin{array}{l}-0.064 \\
(0.053)\end{array}$ & $\begin{array}{l}2.843 * * * \\
(0.492)\end{array}$ & $\begin{array}{l}-0.043 \\
(0.106)\end{array}$ \\
\hline Language $_{\mathrm{ij}}$ & $\begin{array}{l}0.052 \\
(0.125)\end{array}$ & $\begin{array}{l}0.031 \\
(0.052)\end{array}$ & $\begin{array}{l}0.081 \\
(0.069)\end{array}$ & $\begin{array}{l}-0.085 \\
(0.070)\end{array}$ & $\begin{array}{l}-4.683 * * * \\
(0.806)\end{array}$ & $\begin{array}{l}0.200 * \\
(0.078)\end{array}$ & $\begin{array}{l}-5.489 * * * \\
(0.824)\end{array}$ & $\begin{array}{l}0.199 \\
(0.111)\end{array}$ \\
\hline Trade $_{\mathrm{ij}, \mathrm{t}-1}$ & $\begin{array}{l}0.087 \\
(0.063)\end{array}$ & $\begin{array}{l}0.070^{*} \\
(0.033)\end{array}$ & $\begin{array}{l}-0.033 \\
(0.029)\end{array}$ & $\begin{array}{l}0.058 \\
(0.038)\end{array}$ & $\begin{array}{l}0.211 \\
(0.195)\end{array}$ & $\begin{array}{l}0.156^{\text {** }} \\
(0.048)\end{array}$ & $\begin{array}{l}-0.133 \\
(0.187)\end{array}$ & $\begin{array}{l}0.125 \\
(0.069)\end{array}$ \\
\hline Fixed $F X_{\mathrm{ij}, \mathrm{t}}$ & $\begin{array}{l}-0.106 \\
(0.146)\end{array}$ & $\begin{array}{l}-0.090 \\
(0.066)\end{array}$ & $\begin{array}{l}0.057 \\
(0.063)\end{array}$ & $\begin{array}{l}-0.040 \\
(0.089)\end{array}$ & $\begin{array}{l}0.831 * \\
(0.322)\end{array}$ & $\begin{array}{l}-0.196 \\
(0.164)\end{array}$ & $\begin{array}{l}1.291 * * * \\
(0.285)\end{array}$ & $\begin{array}{l}-0.124 \\
(0.117)\end{array}$ \\
\hline $\begin{array}{l}\mathrm{R}^{2} \\
\text { Obs }\end{array}$ & $\begin{array}{l}0.514 \\
1603\end{array}$ & $\begin{array}{l}0.432 \\
1504\end{array}$ & $\begin{array}{l}0.503 \\
1575\end{array}$ & $\begin{array}{l}0.560 \\
1559\end{array}$ & $\begin{array}{l}0.480 \\
1588\end{array}$ & $\begin{array}{l}0.380 \\
1386\end{array}$ & $\begin{array}{l}0.549 \\
1503\end{array}$ & $\begin{array}{l}0.504 \\
1553\end{array}$ \\
\hline
\end{tabular}

Notes: Dependent variables are annual bilateral capital flows in \% of reporting country GDP. All specifications include reporter-year and partner-year dummy variables. Robust standard errors in parentheses. ${ }^{* * *},{ }^{* *}$, and ${ }^{*}$ denote significance at $1 \%, 5 \%$, and $10 \%$ respectively. 
Table 6D: Bilateral Capital Flows on Gravity Factors

(Using reporter, partner, and year dummy variables)

\begin{tabular}{|c|c|c|c|c|c|c|c|c|}
\hline & $\begin{array}{l}\text { (1) } \\
\text { FINA }\end{array}$ & $\begin{array}{l}\text { (2) } \\
\text { FDIA } \\
\end{array}$ & $\begin{array}{l}\text { (3) } \\
\text { PORTA }\end{array}$ & $\begin{array}{l}\text { (4) } \\
\text { OIA } \\
\end{array}$ & $\begin{array}{l}\text { (5) } \\
\text { FINL } \\
\end{array}$ & $\begin{array}{l}\text { (6) } \\
\text { FDIL } \\
\end{array}$ & $\begin{array}{l}\text { (7) } \\
\text { PORTL }\end{array}$ & $\begin{array}{l}\text { (8) } \\
\text { OIL } \\
\end{array}$ \\
\hline Distance $_{i j}$ & $\begin{array}{l}-0.155^{* *} \\
(0.050)\end{array}$ & $\begin{array}{l}-0.048^{* *} \\
(0.018)\end{array}$ & $\begin{array}{l}-0.060 * * \\
(0.021)\end{array}$ & $\begin{array}{l}-0.046 \\
(0.037)\end{array}$ & $\begin{array}{l}-0.230^{*} \\
(0.106)\end{array}$ & $\begin{array}{l}-0.069^{*} \\
(0.030)\end{array}$ & $\begin{array}{l}-0.184 \\
(0.097)\end{array}$ & $\begin{array}{l}-0.014 \\
(0.037)\end{array}$ \\
\hline Colony $_{\mathrm{ij}}$ & $\begin{array}{l}-0.193 \\
(0.135)\end{array}$ & $\begin{array}{l}-0.051 \\
(0.083)\end{array}$ & $\begin{array}{l}-0.127^{*} \\
(0.054)\end{array}$ & $\begin{array}{l}-0.212 * * \\
(0.080)\end{array}$ & $\begin{array}{l}-0.880 * * * \\
(0.232)\end{array}$ & $\begin{array}{l}0.021 \\
(0.114)\end{array}$ & $\begin{array}{l}-1.046^{* * * *} \\
(0.180)\end{array}$ & $\begin{array}{l}-0.157 \\
(0.098)\end{array}$ \\
\hline Legal $_{i j}$ & $\begin{array}{l}0.203^{*} \\
(0.088)\end{array}$ & $\begin{array}{l}0.053 \\
(0.052)\end{array}$ & $\begin{array}{l}-0.005 \\
(0.033)\end{array}$ & $\begin{array}{l}0.175^{* *} \\
(0.062)\end{array}$ & $\begin{array}{l}1.647 * * * \\
(0.230)\end{array}$ & $\begin{array}{l}0.037 \\
(0.057)\end{array}$ & $\begin{array}{l}1.586^{* * *} \\
(0.218)\end{array}$ & $\begin{array}{l}0.090 \\
(0.080)\end{array}$ \\
\hline Language $_{\mathrm{ij}}$ & $\begin{array}{l}-0.262 \\
(0.137)\end{array}$ & $\begin{array}{l}-0.149 \\
(0.109)\end{array}$ & $\begin{array}{l}-0.007 \\
(0.050)\end{array}$ & $\begin{array}{l}-0.200^{*} \\
(0.079)\end{array}$ & $\begin{array}{l}-3.731 \text { *** } \\
(0.401)\end{array}$ & $\begin{array}{l}-0.068 \\
(0.123)\end{array}$ & $\begin{array}{l}-3.786^{* * * *} \\
(0.385)\end{array}$ & $\begin{array}{l}-0.065 \\
(0.089)\end{array}$ \\
\hline Trade $_{\mathrm{ij}, \mathrm{t}-1}$ & $\begin{array}{l}0.137 * * * \\
(0.033)\end{array}$ & $\begin{array}{l}0.062^{* * * *} \\
(0.011)\end{array}$ & $\begin{array}{l}0.030 \\
(0.017)\end{array}$ & $\begin{array}{l}0.042 \\
(0.023)\end{array}$ & $\begin{array}{l}0.382^{* * *} \\
(0.039)\end{array}$ & $\begin{array}{l}0.043^{*} \\
(0.017)\end{array}$ & $\begin{array}{l}0.258^{* * * *} \\
(0.029)\end{array}$ & $\begin{array}{l}0.074 * * * * \\
(0.013)\end{array}$ \\
\hline Fixed & $\begin{array}{l}-0.063 \\
(0.086)\end{array}$ & $\begin{array}{l}-0.085^{* *} \\
(0.031)\end{array}$ & $\begin{array}{l}0.077^{*} \\
(0.031)\end{array}$ & $\begin{array}{l}0.050 \\
(0.056)\end{array}$ & $\begin{array}{l}-0.236 \\
(0.192)\end{array}$ & $\begin{array}{l}-0.080 \\
(0.047)\end{array}$ & $\begin{array}{l}0.038 \\
(0.172)\end{array}$ & $\begin{array}{l}0.019 \\
(0.066)\end{array}$ \\
\hline $\begin{array}{l}\mathrm{R}^{2} \\
\text { Obs }\end{array}$ & $\begin{array}{l}0.218 \\
2657\end{array}$ & $\begin{array}{l}0.102 \\
2506\end{array}$ & $\begin{array}{l}0.280 \\
2593\end{array}$ & $\begin{array}{l}0.083 \\
2585\end{array}$ & $\begin{array}{l}0.273 \\
2646\end{array}$ & $\begin{array}{l}0.062 \\
2393\end{array}$ & $\begin{array}{l}0.335 \\
2494\end{array}$ & $\begin{array}{l}0.074 \\
2559\end{array}$ \\
\hline
\end{tabular}

Notes: Dependent variables are annual bilateral capital flows in \% of reporting country GDP. All specifications include reporter, partner and year dummy variables. Robust standard errors in parentheses. ${ }^{* * *},{ }^{* *}$, and ${ }^{*}$ denote significance at $1 \%, 5 \%$, and $10 \%$ respectively. 
Table 7: Bilateral Capital Flows on Market Size and Transaction Costs

\begin{tabular}{|c|c|c|c|c|c|c|c|c|}
\hline & $\begin{array}{l}\text { (1) } \\
\text { FINA }\end{array}$ & $\begin{array}{l}\text { (2) } \\
\text { FDIA }\end{array}$ & $\begin{array}{l}\text { (3) } \\
\text { PORTA }\end{array}$ & $\begin{array}{l}\text { (4) } \\
\text { OIA }\end{array}$ & $\begin{array}{l}\text { (5) } \\
\text { FINL }\end{array}$ & $\begin{array}{l}\text { (6) } \\
\text { FDIL }\end{array}$ & $\begin{array}{l}(7) \\
\text { PORTL }\end{array}$ & $\begin{array}{l}\text { (8) } \\
\text { OIL }\end{array}$ \\
\hline Per Capita $_{\mathrm{j}, \mathrm{t}-1}$ & $\begin{array}{l}0.398 * * * \\
(0.095)\end{array}$ & $\begin{array}{l}0.066 \\
(0.053)\end{array}$ & $\begin{array}{l}0.176 * * * \\
(0.044)\end{array}$ & $\begin{array}{l}0.227 * * * \\
(0.057)\end{array}$ & $\begin{array}{l}0.656^{* * * *} \\
(0.191)\end{array}$ & $\begin{array}{l}0.200 * \\
(0.091)\end{array}$ & $\begin{array}{l}0.303 \\
(0.187)\end{array}$ & $\begin{array}{l}0.253 * * * \\
(0.063)\end{array}$ \\
\hline Per Capita $_{\mathrm{i}, \mathrm{t}-1}$ & $\begin{array}{l}-1.903 \\
(1.285)\end{array}$ & $\begin{array}{l}-0.340 \\
(1.195)\end{array}$ & $\begin{array}{l}-0.446 \\
(0.406)\end{array}$ & $\begin{array}{l}-1.504^{*} \\
(0.608)\end{array}$ & $\begin{array}{l}0.044 \\
(1.445)\end{array}$ & $\begin{array}{l}0.374 \\
(0.839)\end{array}$ & $\begin{array}{l}-1.447 \\
(0.968)\end{array}$ & $\begin{array}{l}0.878 \\
(0.705)\end{array}$ \\
\hline Internet $_{j}$ & $\begin{array}{l}0.028 \\
(0.046)\end{array}$ & $\begin{array}{l}0.017 \\
(0.054)\end{array}$ & $\begin{array}{l}-0.019 \\
(0.014)\end{array}$ & $\begin{array}{l}0.001 \\
(0.016)\end{array}$ & $\begin{array}{l}0.090 \\
(0.060)\end{array}$ & $\begin{array}{l}0.076 \\
(0.054)\end{array}$ & $\begin{array}{l}-0.051 \\
(0.032)\end{array}$ & $\begin{array}{l}0.051 * * \\
(0.020)\end{array}$ \\
\hline Internet $_{\mathrm{i}}$ & $\begin{array}{l}-0.361^{*} \\
(0.155)\end{array}$ & $\begin{array}{l}-0.067 \\
(0.185)\end{array}$ & $\begin{array}{l}-0.144^{*} \\
(0.057)\end{array}$ & $\begin{array}{l}-0.148^{* *} \\
(0.046)\end{array}$ & $\begin{array}{l}-0.532 * * * \\
(0.154)\end{array}$ & $\begin{array}{l}-0.267^{*} \\
(0.123)\end{array}$ & $\begin{array}{l}-0.126^{*} \\
(0.062)\end{array}$ & $\begin{array}{l}-0.101 \\
(0.064)\end{array}$ \\
\hline Corruption Control $\mathrm{j}_{\mathrm{j}, \mathrm{t}-1}$ & $\begin{array}{l}0.006^{*} \\
(0.003)\end{array}$ & $\begin{array}{l}0.001 \\
(0.002)\end{array}$ & $\begin{array}{l}0.004 * * \\
(0.001)\end{array}$ & $\begin{array}{l}0.001 \\
(0.002)\end{array}$ & $\begin{array}{l}-0.017 * * * * \\
(0.005)\end{array}$ & $\begin{array}{l}-0.003 \\
(0.003)\end{array}$ & $\begin{array}{l}-0.015^{* * * *} \\
(0.004)\end{array}$ & $\begin{array}{l}-0.002 \\
(0.002)\end{array}$ \\
\hline Corruption Control $_{\mathrm{i}, \mathrm{t}-1}$ & $\begin{array}{l}0.024^{*} \\
(0.011)\end{array}$ & $\begin{array}{l}0.003 \\
(0.009)\end{array}$ & $\begin{array}{l}0.011^{*} \\
(0.004)\end{array}$ & $\begin{array}{l}0.018^{* *} \\
(0.006)\end{array}$ & $\begin{array}{l}0.070 * * * \\
(0.019)\end{array}$ & $\begin{array}{l}0.029 * \\
(0.013)\end{array}$ & $\begin{array}{l}0.031^{*} \\
(0.015)\end{array}$ & $\begin{array}{l}0.021 * * * \\
(0.005)\end{array}$ \\
\hline Capital Openness $_{\mathrm{j}, \mathrm{t}-1}$ & $\begin{array}{l}0.153 \\
(0.091)\end{array}$ & $\begin{array}{l}-0.042 \\
(0.050)\end{array}$ & $\begin{array}{l}0.103 * * \\
(0.036)\end{array}$ & $\begin{array}{l}0.081 \\
(0.057)\end{array}$ & $\begin{array}{l}-0.009 \\
(0.133)\end{array}$ & $\begin{array}{l}0.051 \\
(0.062)\end{array}$ & $\begin{array}{l}-0.011 \\
(0.103)\end{array}$ & $\begin{array}{l}-0.027 \\
(0.051)\end{array}$ \\
\hline Capital Openness $_{\mathrm{i}, \mathrm{t}-1}$ & $\begin{array}{l}5.827 * * * \\
(1.400)\end{array}$ & $\begin{array}{l}1.096 \\
(1.078)\end{array}$ & $\begin{array}{l}2.281 * * \\
(0.816)\end{array}$ & $\begin{array}{l}2.651^{* * *} \\
(0.528)\end{array}$ & $\begin{array}{l}5.682 * * * \\
(1.612)\end{array}$ & $\begin{array}{l}2.228^{*} \\
(1.061)\end{array}$ & $\begin{array}{l}2.969 * \\
(1.279)\end{array}$ & $\begin{array}{l}0.309 \\
(0.669)\end{array}$ \\
\hline Financial Centre $_{j}$ & $\begin{array}{l}2.602 * \\
(1.015)\end{array}$ & $\begin{array}{l}0.631 \\
(0.981)\end{array}$ & $\begin{array}{l}0.986^{*} \\
(0.405)\end{array}$ & $\begin{array}{l}1.002^{*} \\
(0.397)\end{array}$ & $\begin{array}{l}4.336^{* * *} \\
(1.006)\end{array}$ & $\begin{array}{l}1.817^{*} \\
(0.715)\end{array}$ & $\begin{array}{l}1.731 * \\
(0.739)\end{array}$ & $\begin{array}{l}1.053^{*} \\
(0.458)\end{array}$ \\
\hline Financial Centre $_{i}$ & $\begin{array}{l}-2.243 \\
(1.296)\end{array}$ & $\begin{array}{l}-0.519 \\
(1.366)\end{array}$ & $\begin{array}{l}-1.049 * \\
(0.472)\end{array}$ & $\begin{array}{l}-0.574 \\
(0.501)\end{array}$ & $\begin{array}{l}-3.830 * * \\
(1.211)\end{array}$ & $\begin{array}{l}-1.774 * \\
(0.836)\end{array}$ & $\begin{array}{l}-0.739 \\
(0.788)\end{array}$ & $\begin{array}{l}-1.225^{*} \\
(0.597)\end{array}$ \\
\hline $\begin{array}{l}\mathrm{R}^{2} \\
\text { Obs }\end{array}$ & $\begin{array}{l}0.286 \\
2595\end{array}$ & $\begin{array}{l}0.130 \\
2447\end{array}$ & $\begin{array}{l}0.363 \\
2534\end{array}$ & $\begin{array}{l}0.138 \\
2522\end{array}$ & $\begin{array}{l}0.581 \\
2579\end{array}$ & $\begin{array}{l}0.095 \\
2343\end{array}$ & $\begin{array}{l}0.756 \\
2437\end{array}$ & $\begin{array}{l}0.120 \\
2504\end{array}$ \\
\hline
\end{tabular}

Notes: Dependent variables are annual bilateral capital flows in \% of reporting country GDP. All specifications include reporter-partner and year dummy variables. Robust standard errors in parentheses. ${ }^{* * *},{ }^{* *}$, and ${ }^{*}$ denote significance at $1 \%, 5 \%$, and $10 \%$ respectively. 
Table 8A: Bilateral Capital Flows on Market Size and Transaction Costs (removing 2008 and 2009)

\begin{tabular}{|c|c|c|c|c|c|c|c|c|}
\hline & $\begin{array}{l}\text { (1) } \\
\text { FINA }\end{array}$ & $\begin{array}{l}(2) \\
\text { FDIA }\end{array}$ & $\begin{array}{l}(3) \\
\text { PORTA }\end{array}$ & $\begin{array}{l}(4) \\
\text { OIA }\end{array}$ & $\begin{array}{l}\text { (5) } \\
\text { FINL }\end{array}$ & $\begin{array}{l}(6) \\
\text { FDIL }\end{array}$ & $\begin{array}{l}(7) \\
\text { PORTL }\end{array}$ & $\begin{array}{l}(8) \\
\text { OIL }\end{array}$ \\
\hline Per Capita $_{\mathrm{j}, \mathrm{t}-1}$ & $\begin{array}{l}0.375 * * * \\
(0.095)\end{array}$ & $\begin{array}{l}0.053 \\
(0.054)\end{array}$ & $\begin{array}{l}0.176 * * * \\
(0.045)\end{array}$ & $\begin{array}{l}0.231 * * * \\
(0.056)\end{array}$ & $\begin{array}{l}0.671 * * * \\
(0.194)\end{array}$ & $\begin{array}{l}0.180 \\
(0.092)\end{array}$ & $\begin{array}{l}0.348 \\
(0.192)\end{array}$ & $\begin{array}{l}0.247 * * * \\
(0.063)\end{array}$ \\
\hline Per Capita ${ }_{i, t-1}$ & $\begin{array}{l}-1.341 \\
(1.230)\end{array}$ & $\begin{array}{l}-0.007 \\
(1.202)\end{array}$ & $\begin{array}{l}-0.426 \\
(0.415)\end{array}$ & $\begin{array}{l}-1.025 \\
(0.578)\end{array}$ & $\begin{array}{l}0.714 \\
(1.466)\end{array}$ & $\begin{array}{l}1.030 \\
(0.843)\end{array}$ & $\begin{array}{l}-1.526 \\
(1.012)\end{array}$ & $\begin{array}{l}0.970 \\
(0.717)\end{array}$ \\
\hline Internet $_{\mathrm{j}}$ & $\begin{array}{l}0.048 \\
(0.047)\end{array}$ & $\begin{array}{l}0.018 \\
(0.056)\end{array}$ & $\begin{array}{l}-0.015 \\
(0.015)\end{array}$ & $\begin{array}{l}0.015 \\
(0.016)\end{array}$ & $\begin{array}{l}0.113 \\
(0.065)\end{array}$ & $\begin{array}{l}0.081 \\
(0.061)\end{array}$ & $\begin{array}{l}-0.047 \\
(0.033)\end{array}$ & $\begin{array}{l}0.062 * * \\
(0.020)\end{array}$ \\
\hline Internet $_{\mathrm{i}}$ & $\begin{array}{l}-0.322 \\
(0.182)\end{array}$ & $\begin{array}{l}-0.041 \\
(0.225)\end{array}$ & $\begin{array}{l}-0.154 * \\
(0.068)\end{array}$ & $\begin{array}{l}-0.147 * * \\
(0.052)\end{array}$ & $\begin{array}{l}-0.517 * * \\
(0.183)\end{array}$ & $\begin{array}{l}-0.272 \\
(0.158)\end{array}$ & $\begin{array}{l}-0.126 \\
(0.066)\end{array}$ & $\begin{array}{l}-0.094 \\
(0.070)\end{array}$ \\
\hline Corruption Control $_{\mathrm{j}, \mathrm{t}-1}$ & $\begin{array}{l}0.006 * \\
(0.003)\end{array}$ & $\begin{array}{l}0.002 \\
(0.003)\end{array}$ & $\begin{array}{l}0.004 * * \\
(0.001)\end{array}$ & $\begin{array}{l}-0.000 \\
(0.001)\end{array}$ & $\begin{array}{l}-0.017 * * * \\
(0.005)\end{array}$ & $\begin{array}{l}-0.002 \\
(0.004)\end{array}$ & $\begin{array}{l}-0.016^{* * *} \\
(0.004)\end{array}$ & $\begin{array}{l}-0.002 \\
(0.002)\end{array}$ \\
\hline Corruption Control $_{\mathrm{i}, \mathrm{t}-1}$ & $\begin{array}{l}0.024 * \\
(0.012)\end{array}$ & $\begin{array}{l}0.001 \\
(0.011)\end{array}$ & $\begin{array}{l}0.014 * * \\
(0.004)\end{array}$ & $\begin{array}{l}0.017 * * \\
(0.006)\end{array}$ & $\begin{array}{l}0.072 * * * \\
(0.021)\end{array}$ & $\begin{array}{l}0.031 * \\
(0.015)\end{array}$ & $\begin{array}{l}0.031 * \\
(0.015)\end{array}$ & $\begin{array}{l}0.021 * * * \\
(0.006)\end{array}$ \\
\hline Capital Openness $_{\mathrm{j}, \mathrm{t}-1}$ & $\begin{array}{l}0.057 \\
(0.092)\end{array}$ & $\begin{array}{l}-0.064 \\
(0.053)\end{array}$ & $\begin{array}{l}0.100 * * \\
(0.038)\end{array}$ & $\begin{array}{l}0.014 \\
(0.056)\end{array}$ & $\begin{array}{l}-0.076 \\
(0.144)\end{array}$ & $\begin{array}{l}0.048 \\
(0.074)\end{array}$ & $\begin{array}{l}-0.018 \\
(0.110)\end{array}$ & $\begin{array}{l}-0.065 \\
(0.052)\end{array}$ \\
\hline Capital Openness $_{\mathrm{i}, \mathrm{t}-1}$ & $\begin{array}{l}4.883 * * \\
(1.705)\end{array}$ & $\begin{array}{l}0.972 \\
(1.706)\end{array}$ & $\begin{array}{l}1.804 * \\
(0.910)\end{array}$ & $\begin{array}{l}2.897 * * * \\
(0.637)\end{array}$ & $\begin{array}{l}5.842 * * \\
(2.190)\end{array}$ & $\begin{array}{l}2.953 * \\
(1.437)\end{array}$ & $\begin{array}{l}2.947 \\
(1.554)\end{array}$ & $\begin{array}{l}0.291 \\
(0.714)\end{array}$ \\
\hline Financial Centre $_{j}$ & $\begin{array}{l}2.469 * \\
(1.163)\end{array}$ & $\begin{array}{l}0.703 \\
(1.246)\end{array}$ & $\begin{array}{l}0.900 * \\
(0.409)\end{array}$ & $\begin{array}{l}1.235 * * \\
(0.435)\end{array}$ & $\begin{array}{l}4.630 * * * \\
(1.245)\end{array}$ & $\begin{array}{l}2.366^{*} \\
(0.958)\end{array}$ & $\begin{array}{l}1.630 * \\
(0.804)\end{array}$ & $\begin{array}{l}1.086^{*} \\
(0.490)\end{array}$ \\
\hline Financial Centre $_{i}$ & $\begin{array}{l}-2.247 \\
(1.453)\end{array}$ & $\begin{array}{l}-0.690 \\
(1.668)\end{array}$ & $\begin{array}{l}-0.938 \\
(0.497)\end{array}$ & $\begin{array}{l}-0.966 \\
(0.528)\end{array}$ & $\begin{array}{l}-4.278 * * \\
(1.478)\end{array}$ & $\begin{array}{l}-2.513 * \\
(1.114)\end{array}$ & $\begin{array}{l}-0.590 \\
(0.862)\end{array}$ & $\begin{array}{l}-1.294 * \\
(0.635)\end{array}$ \\
\hline $\begin{array}{l}\mathrm{R}^{2} \\
\text { Obs }\end{array}$ & $\begin{array}{l}0.327 \\
2259\end{array}$ & $\begin{array}{l}0.153 \\
2131\end{array}$ & $\begin{array}{l}0.406 \\
2205\end{array}$ & $\begin{array}{l}0.191 \\
2199\end{array}$ & $\begin{array}{l}0.589 \\
2242\end{array}$ & $\begin{array}{l}0.129 \\
2043\end{array}$ & $\begin{array}{l}0.749 \\
2119\end{array}$ & $\begin{array}{l}0.147 \\
2176\end{array}$ \\
\hline
\end{tabular}

Notes: Dependent variables are annual bilateral capital flows in \% of reporting country GDP. All specifications include reporter-partner and year dummy variables. Robust standard errors in parentheses. ${ }^{* * *},{ }^{* *}$, and ${ }^{*}$ denote significance at $1 \%, 5 \%$, and $10 \%$ respectively. 
Table 8B: Bilateral Capital Flows on Market Size Transaction Costs (without New Zealand)

\begin{tabular}{|c|c|c|c|c|c|c|c|c|}
\hline & $\begin{array}{l}\text { (1) } \\
\text { FINA }\end{array}$ & $\begin{array}{l}(2) \\
\text { FDIA }\end{array}$ & $\begin{array}{l}\text { (3) } \\
\text { PORTA }\end{array}$ & $\begin{array}{l}\text { (4) } \\
\text { OIA }\end{array}$ & $\begin{array}{l}\text { (5) } \\
\text { FINL }\end{array}$ & $\begin{array}{l}\text { (6) } \\
\text { FDIL }\end{array}$ & $\begin{array}{l}(7) \\
\text { PORTL }\end{array}$ & $\begin{array}{l}\text { (8) } \\
\text { OIL }\end{array}$ \\
\hline Per Capita $_{\mathrm{j}, \mathrm{t}-1}$ & $\begin{array}{l}0.494 * * * \\
(0.118)\end{array}$ & $\begin{array}{l}0.050 \\
(0.055)\end{array}$ & $\begin{array}{l}0.236 * * * \\
(0.054)\end{array}$ & $\begin{array}{l}0.249 * * * \\
(0.068)\end{array}$ & $\begin{array}{l}0.725 * * \\
(0.239)\end{array}$ & $\begin{array}{l}0.255^{*} \\
(0.105)\end{array}$ & $\begin{array}{l}0.320 \\
(0.213)\end{array}$ & $\begin{array}{l}0.224 * * * \\
(0.067)\end{array}$ \\
\hline Per Capita $_{i, t-1}$ & $\begin{array}{l}-1.626 \\
(1.615)\end{array}$ & $\begin{array}{l}-0.312 \\
(1.494)\end{array}$ & $\begin{array}{l}-0.513 \\
(0.495)\end{array}$ & $\begin{array}{l}-1.281 \\
(0.681)\end{array}$ & $\begin{array}{l}0.991 \\
(1.662)\end{array}$ & $\begin{array}{l}0.375 \\
(0.954)\end{array}$ & $\begin{array}{l}-0.955 \\
(1.082)\end{array}$ & $\begin{array}{l}1.380 \\
(0.839)\end{array}$ \\
\hline Internet $_{j}$ & $\begin{array}{l}0.031 \\
(0.056)\end{array}$ & $\begin{array}{l}0.024 \\
(0.057)\end{array}$ & $\begin{array}{l}-0.015 \\
(0.017)\end{array}$ & $\begin{array}{l}-0.003 \\
(0.018)\end{array}$ & $\begin{array}{l}0.085 \\
(0.073)\end{array}$ & $\begin{array}{l}0.087 \\
(0.066)\end{array}$ & $\begin{array}{l}-0.057 \\
(0.036)\end{array}$ & $\begin{array}{l}0.036 \\
(0.021)\end{array}$ \\
\hline Internet $_{\mathrm{i}}$ & $\begin{array}{l}-0.357 \\
(0.186)\end{array}$ & $\begin{array}{l}-0.084 \\
(0.210)\end{array}$ & $\begin{array}{l}-0.119 \\
(0.070)\end{array}$ & $\begin{array}{l}-0.149 * * \\
(0.053)\end{array}$ & $\begin{array}{l}-0.590 * * \\
(0.183)\end{array}$ & $\begin{array}{l}-0.275^{*} \\
(0.138)\end{array}$ & $\begin{array}{l}-0.135^{*} \\
(0.066)\end{array}$ & $\begin{array}{l}-0.165^{*} \\
(0.079)\end{array}$ \\
\hline Corruption Control $_{\mathrm{j}, \mathrm{t}-1}$ & $\begin{array}{l}0.006 \\
(0.003)\end{array}$ & $\begin{array}{l}0.002 \\
(0.002)\end{array}$ & $\begin{array}{l}0.003^{*} \\
(0.001)\end{array}$ & $\begin{array}{l}0.001 \\
(0.002)\end{array}$ & $\begin{array}{l}-0.021 * * * \\
(0.005)\end{array}$ & $\begin{array}{l}-0.004 \\
(0.004)\end{array}$ & $\begin{array}{l}-0.018 * * * \\
(0.004)\end{array}$ & $\begin{array}{l}-0.002 \\
(0.002)\end{array}$ \\
\hline Corruption Control $_{\mathrm{i}, \mathrm{t}-1}$ & $\begin{array}{l}0.024 * \\
(0.012)\end{array}$ & $\begin{array}{l}0.003 \\
(0.011)\end{array}$ & $\begin{array}{l}0.010^{*} \\
(0.004)\end{array}$ & $\begin{array}{l}0.018^{* *} \\
(0.006)\end{array}$ & $\begin{array}{l}0.073 * * * \\
(0.020)\end{array}$ & $\begin{array}{l}0.029 * \\
(0.014)\end{array}$ & $\begin{array}{l}0.031^{*} \\
(0.015)\end{array}$ & $\begin{array}{l}0.025^{* * * *} \\
(0.006)\end{array}$ \\
\hline Capital Openness $s_{\mathrm{j},-1}$ & $\begin{array}{l}0.129 \\
(0.098)\end{array}$ & $\begin{array}{l}-0.042 \\
(0.055)\end{array}$ & $\begin{array}{l}0.100^{*} \\
(0.040)\end{array}$ & $\begin{array}{l}0.077 \\
(0.063)\end{array}$ & $\begin{array}{l}0.022 \\
(0.143)\end{array}$ & $\begin{array}{l}0.065 \\
(0.070)\end{array}$ & $\begin{array}{l}-0.066 \\
(0.114)\end{array}$ & $\begin{array}{l}0.032 \\
(0.048)\end{array}$ \\
\hline Capital Openness $_{\mathrm{i}, \mathrm{t}-1}$ & $\begin{array}{l}5.732^{* * * *} \\
(1.390)\end{array}$ & $\begin{array}{l}1.230 \\
(1.015)\end{array}$ & $\begin{array}{l}2.200 * * \\
(0.851)\end{array}$ & $\begin{array}{l}2.474 * * * \\
(0.524)\end{array}$ & $\begin{array}{l}5.465 * * \\
(1.680)\end{array}$ & $\begin{array}{l}2.250^{*} \\
(1.106)\end{array}$ & $\begin{array}{l}2.774 * \\
(1.347)\end{array}$ & $\begin{array}{l}0.420 \\
(0.679)\end{array}$ \\
\hline Financial Centre $_{j}$ & $\begin{array}{l}4.571 * * * \\
(1.179)\end{array}$ & $\begin{array}{l}1.175 \\
(1.208)\end{array}$ & $\begin{array}{l}1.632 * * * \\
(0.450)\end{array}$ & $\begin{array}{l}1.692 * * * \\
(0.389)\end{array}$ & $\begin{array}{l}4.368 * * * \\
(1.180)\end{array}$ & $\begin{array}{l}2.049 * \\
(0.953)\end{array}$ & $\begin{array}{l}0.828 \\
(0.602)\end{array}$ & $\begin{array}{l}1.428 * * \\
(0.495)\end{array}$ \\
\hline Financial Centre $_{i}$ & $\begin{array}{l}-2.382 \\
(1.590)\end{array}$ & $\begin{array}{l}-0.607 \\
(1.607)\end{array}$ & $\begin{array}{l}-0.939 \\
(0.551)\end{array}$ & $\begin{array}{l}-0.666 \\
(0.567)\end{array}$ & $\begin{array}{l}-4.482 * * \\
(1.434)\end{array}$ & $\begin{array}{l}-1.771 \\
(0.960)\end{array}$ & $\begin{array}{l}-1.023 \\
(0.849)\end{array}$ & $\begin{array}{l}-1.716^{*} \\
(0.719)\end{array}$ \\
\hline $\begin{array}{l}\mathrm{R}^{2} \\
\text { Obs }\end{array}$ & $\begin{array}{l}0.297 \\
2193\end{array}$ & $\begin{array}{l}0.131 \\
2171\end{array}$ & $\begin{array}{l}0.373 \\
2176\end{array}$ & $\begin{array}{l}0.153 \\
2185\end{array}$ & $\begin{array}{l}0.591 \\
2193\end{array}$ & $\begin{array}{l}0.091 \\
2044\end{array}$ & $\begin{array}{l}0.766 \\
2177\end{array}$ & $\begin{array}{l}0.110 \\
2188\end{array}$ \\
\hline
\end{tabular}

Notes: Dependent variables are annual bilateral capital flows in \% of reporting country GDP. All specifications include reporter-partner and year dummy variables. Robust standard errors in parentheses. ${ }^{* * *},{ }^{* *}$, and ${ }^{*}$ denote significance at $1 \%, 5 \%$, and $10 \%$ respectively. 
Table 8C: Bilateral Capital Flows on Market Size and Transaction Costs (without reporter market size and transaction costs)

\begin{tabular}{|c|c|c|c|c|c|c|c|c|}
\hline & $\begin{array}{l}(1) \\
\text { FINA }\end{array}$ & $\begin{array}{l}(2) \\
\text { FDIA }\end{array}$ & $\begin{array}{l}(3) \\
\text { PORTA }\end{array}$ & $\begin{array}{l}(4) \\
\text { OIA }\end{array}$ & $\begin{array}{l}(5) \\
\text { FINL } \\
\end{array}$ & $\begin{array}{l}\text { (6) } \\
\text { FDIL } \\
\end{array}$ & $\begin{array}{l}(7) \\
\text { PORTL }\end{array}$ & $\begin{array}{l}(8) \\
\text { OIL }\end{array}$ \\
\hline Per Capita ${ }_{\mathrm{j}, \mathrm{t}-1}$ & $\begin{array}{l}0.492 * * * \\
(0.100)\end{array}$ & $\begin{array}{l}0.084 \\
(0.065)\end{array}$ & $\begin{array}{l}0.213^{* * * *} \\
(0.045)\end{array}$ & $\begin{array}{l}0.278 * * * \\
(0.059)\end{array}$ & $\begin{array}{l}0.783 * * * \\
(0.191)\end{array}$ & $\begin{array}{l}0.247 * \\
(0.101)\end{array}$ & $\begin{array}{l}0.374 * \\
(0.180)\end{array}$ & $\begin{array}{l}0.280 * * * \\
(0.065)\end{array}$ \\
\hline Internet $_{\mathrm{j}}$ & $\begin{array}{l}0.021 \\
(0.043)\end{array}$ & $\begin{array}{l}0.015 \\
(0.046)\end{array}$ & $\begin{array}{l}-0.023 \\
(0.014)\end{array}$ & $\begin{array}{l}0.000 \\
(0.016)\end{array}$ & $\begin{array}{l}0.080 \\
(0.059)\end{array}$ & $\begin{array}{l}0.066 \\
(0.052)\end{array}$ & $\begin{array}{l}-0.053 \\
(0.032)\end{array}$ & $\begin{array}{l}0.048 * \\
(0.019)\end{array}$ \\
\hline Corruption Control $_{\mathrm{j}, \mathrm{t}-1}$ & $\begin{array}{l}0.008 * * * \\
(0.003)\end{array}$ & $\begin{array}{l}0.001 \\
(0.002)\end{array}$ & $\begin{array}{l}0.005 * * * \\
(0.001)\end{array}$ & $\begin{array}{l}0.001 \\
(0.002)\end{array}$ & $\begin{array}{l}-0.015^{* *} \\
(0.005)\end{array}$ & $\begin{array}{l}-0.001 \\
(0.003)\end{array}$ & $\begin{array}{l}-0.015 * * * \\
(0.003)\end{array}$ & $\begin{array}{l}-0.002 \\
(0.002)\end{array}$ \\
\hline Capital Openness $_{\mathrm{j}, \mathrm{t}-1}$ & $\begin{array}{l}0.077 \\
(0.085)\end{array}$ & $\begin{array}{l}-0.057 \\
(0.048)\end{array}$ & $\begin{array}{l}0.072 * \\
(0.032)\end{array}$ & $\begin{array}{l}0.033 \\
(0.054)\end{array}$ & $\begin{array}{l}-0.122 \\
(0.126)\end{array}$ & $\begin{array}{l}0.009 \\
(0.057)\end{array}$ & $\begin{array}{l}-0.071 \\
(0.104)\end{array}$ & $\begin{array}{l}-0.051 \\
(0.048)\end{array}$ \\
\hline Financial Centre $_{j}$ & $\begin{array}{l}0.347 \\
(0.183)\end{array}$ & $\begin{array}{l}0.276^{* * * *} \\
(0.074)\end{array}$ & $\begin{array}{l}-0.046 \\
(0.147)\end{array}$ & $\begin{array}{l}0.051 \\
(0.121)\end{array}$ & $\begin{array}{l}0.005 \\
(0.192)\end{array}$ & $\begin{array}{l}-0.082 \\
(0.128)\end{array}$ & $\begin{array}{l}0.222 \\
(0.140)\end{array}$ & $\begin{array}{l}-0.090 \\
(0.095)\end{array}$ \\
\hline $\begin{array}{l}\mathrm{R}^{2} \\
\text { Obs }\end{array}$ & $\begin{array}{l}0.280 \\
2595\end{array}$ & $\begin{array}{l}0.129 \\
2447\end{array}$ & $\begin{array}{l}0.355 \\
2534\end{array}$ & $\begin{array}{l}0.128 \\
2522\end{array}$ & $\begin{array}{l}0.576 \\
2579\end{array}$ & $\begin{array}{l}0.090 \\
2343\end{array}$ & $\begin{array}{l}0.755 \\
2437\end{array}$ & $\begin{array}{l}0.115 \\
2504\end{array}$ \\
\hline
\end{tabular}

Notes: Dependent variables are annual bilateral capital flows in \% of reporting country GDP. All specifications include reporter-partner and year dummy variables. Robust standard errors in parentheses. ${ }^{* * *},{ }^{* *}$, and ${ }^{*}$ denote significance at $1 \%, 5 \%$, and $10 \%$ respectively. 
Table 8D: Bilateral Capital Flows on Market Size and Transaction Costs (without partner market size and transaction costs)

\begin{tabular}{|c|c|c|c|c|c|c|c|c|}
\hline & $\begin{array}{l}\text { (1) } \\
\text { FINA }\end{array}$ & $\begin{array}{l}(2) \\
\text { FDIA }\end{array}$ & $\begin{array}{l}\text { (3) } \\
\text { PORTA }\end{array}$ & $\begin{array}{l}\text { (4) } \\
\text { OIA }\end{array}$ & $\begin{array}{l}\text { (5) } \\
\text { FINL }\end{array}$ & $\begin{array}{l}(6) \\
\text { FDIL }\end{array}$ & $\begin{array}{l}(7) \\
\text { PORTL }\end{array}$ & $\begin{array}{l}\text { (8) } \\
\text { OIL }\end{array}$ \\
\hline Per Capita ${ }_{i, t-1}$ & $\begin{array}{l}-1.943 \\
(1.241)\end{array}$ & $\begin{array}{l}-0.379 \\
(1.094)\end{array}$ & $\begin{array}{l}-0.438 \\
(0.393)\end{array}$ & $\begin{array}{l}-1.496^{*} \\
(0.588)\end{array}$ & $\begin{array}{l}-0.121 \\
(1.407)\end{array}$ & $\begin{array}{l}0.311 \\
(0.820)\end{array}$ & $\begin{array}{l}-1.377 \\
(0.939)\end{array}$ & $\begin{array}{l}0.741 \\
(0.677)\end{array}$ \\
\hline Internet $_{\mathrm{i}}$ & $\begin{array}{l}-0.372^{*} \\
(0.150)\end{array}$ & $\begin{array}{l}-0.067 \\
(0.175)\end{array}$ & $\begin{array}{l}-0.151 * * \\
(0.055)\end{array}$ & $\begin{array}{l}-0.153^{* * * *} \\
(0.045)\end{array}$ & $\begin{array}{l}-0.522 * * * * \\
(0.148)\end{array}$ & $\begin{array}{l}-0.263^{*} \\
(0.119)\end{array}$ & $\begin{array}{l}-0.126^{*} \\
(0.060)\end{array}$ & $\begin{array}{l}-0.101 \\
(0.062)\end{array}$ \\
\hline Corruption Control $_{\mathrm{i}, \mathrm{t}-1}$ & $\begin{array}{l}0.026^{*} \\
(0.011)\end{array}$ & $\begin{array}{l}0.003 \\
(0.009)\end{array}$ & $\begin{array}{l}0.012^{* *} \\
(0.004)\end{array}$ & $\begin{array}{l}0.018^{* * *} \\
(0.005)\end{array}$ & $\begin{array}{l}0.070^{* * * *} \\
(0.019)\end{array}$ & $\begin{array}{l}0.027^{*} \\
(0.013)\end{array}$ & $\begin{array}{l}0.030^{*} \\
(0.014)\end{array}$ & $\begin{array}{l}0.022^{* * *} \\
(0.005)\end{array}$ \\
\hline Capital Openness $s_{i,-1}$ & $\begin{array}{l}6.140 * * * \\
(1.359)\end{array}$ & $\begin{array}{l}1.148 \\
(1.036)\end{array}$ & $\begin{array}{l}2.459 * * \\
(0.796)\end{array}$ & $\begin{array}{l}2.752 * * * \\
(0.527)\end{array}$ & $\begin{array}{l}5.689 * * * \\
(1.580)\end{array}$ & $\begin{array}{l}2.236^{*} \\
(1.060)\end{array}$ & $\begin{array}{l}2.831 * \\
(1.266)\end{array}$ & $\begin{array}{l}0.471 \\
(0.660)\end{array}$ \\
\hline Financial Centre $_{i}$ & $\begin{array}{l}-2.464^{*} \\
(1.248)\end{array}$ & $\begin{array}{l}-0.529 \\
(1.268)\end{array}$ & $\begin{array}{l}-1.191 * * \\
(0.452)\end{array}$ & $\begin{array}{l}-0.679 \\
(0.487)\end{array}$ & $\begin{array}{l}-3.876^{* * * *} \\
(1.174)\end{array}$ & $\begin{array}{l}-1.762 * \\
(0.815)\end{array}$ & $\begin{array}{l}-0.794 \\
(0.761)\end{array}$ & $\begin{array}{l}-1.263^{*} \\
(0.580)\end{array}$ \\
\hline $\begin{array}{l}\mathrm{R}^{2} \\
\text { Obs }\end{array}$ & $\begin{array}{l}0.286 \\
2673\end{array}$ & $\begin{array}{l}0.130 \\
2526\end{array}$ & $\begin{array}{l}0.365 \\
2611\end{array}$ & $\begin{array}{l}0.136 \\
2600\end{array}$ & $\begin{array}{l}0.579 \\
2663\end{array}$ & $\begin{array}{l}0.093 \\
2401\end{array}$ & $\begin{array}{l}0.755 \\
2504\end{array}$ & $\begin{array}{l}0.117 \\
2574\end{array}$ \\
\hline
\end{tabular}

